European School of Oncology - Review

\title{
Considerations on antimicrobial prophylaxis in patients with lymphoproliferative diseases: A SEIFEM group position paper
}

\author{
Alessandro Busca $^{\mathrm{a}, *}$, Chiara Cattaneo ${ }^{\mathrm{b}}$, Elena De Carolis ${ }^{\mathrm{c}}$, Gianpaolo Nadali ${ }^{\mathrm{d}}$, \\ Massimo Offidani ${ }^{\mathrm{e}}$, Marco Picardi ${ }^{\mathrm{f}}$, Anna Candoni ${ }^{\mathrm{g}}$, Eleonora Ceresoli ${ }^{\mathrm{h}}$, Marianna Criscuolo ${ }^{\mathrm{i}}$, \\ Mario Delia $^{\mathrm{j}}$, Roberta Della Pepa ${ }^{\mathrm{k}}$, Ilaria Del Principe ${ }^{1}$, Roma. Rosa Fanci ${ }^{\mathrm{m}}$, Francesca Farina ${ }^{\mathrm{n}}$, \\ Nicola Fracchiolla $^{\mathrm{o}}$, Claudia Giordano ${ }^{\mathrm{k}}$, Michele Malagola ${ }^{\mathrm{p}}$, Francesco Marchesi ${ }^{\mathrm{q}}$, \\ Monica Piedimonte $^{\mathrm{r}}$, Lucia Prezioso ${ }^{\mathrm{s}}$, Angela Maria Quinto ${ }^{\mathrm{t}}$, Angelica Spolzino ${ }^{\mathrm{r}}$, \\ Maria Chiara Tisi ${ }^{\mathrm{u}}$, Fabio Trastulli ${ }^{\mathrm{k}}$, Enrico Maria Trecarichi ${ }^{\mathrm{v}}$, Patrizia Zappasodi ${ }^{\mathrm{w}}$, \\ Mario Tumbarello ${ }^{\mathrm{x}}$, Livio Pagano ${ }^{\mathrm{x}}$, on behalf of SEIFEM (Sorveglianza Epidemiologica delle \\ InFezioni nelle EMopatie)
}

\footnotetext{
a Stem Cell Transplant Center, AOU Citta' della Salute e della Scienza, Turin, Italy

${ }^{\mathrm{b}}$ Divisione di Ematologia, ASST-Spedali Civili di Brescia, Brescia, Chiara, Italy

${ }^{\mathrm{c}}$ Dipartimento di Scienze di Laboratorio e Infettivologiche, Fondazione Policlinico Universitario "A. Gemelli" IRCCS, Rome, Italy

${ }^{\mathrm{d}}$ U.O.C. Ematologia, AOU Integrata di Verona, Ospedale Borgo Roma, Verona, Italy

${ }^{\text {e }}$ Clinica di Ematologia, AOU Ospedali Riuniti di Ancona, Ancona, Italy

${ }^{\mathrm{f}}$ Department of Advanced Biomedical Science, Federico II University, Italy

${ }^{g}$ Clinica Ematologica, Centro Trapianti e Terapie Cellulari, Azienda Sanitaria Universitaria Integrata di Udine, Italy

${ }^{\mathrm{h}}$ Ematologia Azienda Ospedaliera San Giovanni Addolorata, Rome, Italy

${ }^{\mathrm{i}}$ Dipartimento di scienze radiologiche, radioterapiche ed ematologiche Fondazione Policlinico Universitario A. Gemelli IRCCS Roma, Italy

${ }^{\mathrm{j}}$ U.O.: Ematologia con Trapianto Azienda Ospedaliero-Universitaria Dipartimento dell'Emergenza e Dei Trapianti di Organo Policlinico di Bari, Italy

${ }^{\mathrm{k}}$ Department of Clinical Medicine and Surgery", University of Federico II Naples, Italy

${ }^{1}$ Ematologia, Dipartimento di Biomedicina e Prevenzione, Università degli studi di Roma "Tor Vergata", Italy

${ }^{\mathrm{m}}$ Hematology Department, Careggi Hospital and University of Florence, Italy

${ }^{\mathrm{n}}$ U.O. Ematologia e Trapianto di Midollo - IRCCS Ospedale San Raffaele, Milano, Italy

${ }^{\circ}$ Fondazione IRCCS Ca' Granda Ospedale Maggiore Policlinico di Milano, Italy

${ }^{\mathrm{p}}$ Department of Clinical and Experimental Sciences, University of Brescia, Bone Marrow Transplant Unit, ASST Spedali Civili of Brescia, Italy

${ }^{\mathrm{q}}$ Hematology and Stem Cell Transplant Unit, IRCCS Regina Elena National Cancer Institute, Rome, Italy

${ }^{\mathrm{r}}$ Department of Clinical and Molecular Medicine, Hematology Sant'Andrea University Hospital, Sapienza University of Rome, Italy

${ }^{\mathrm{s}}$ Hematology and BMT Unit, Azienda Ospedaliero-Universitaria di Parma and Department of Medicine and Surgery, University of Parma, Italy

${ }^{\mathrm{t}}$ UO Ematologia e Terapia Cellulare, IRCCS - Istituto Tumori "Giovanni Paolo II" Bari, Italy

"Cell Therapy and Hematology, San Bortolo Hospital, Vicenza, Italy

${ }^{v}$ Dipartimento di Scienze Mediche e Chirurgiche, UO Malattie Infettive e Tropicali, Università degli Studi "Magna Graecia", Catanzaro, Italy

${ }^{\mathrm{w}}$ Division of Hematology, Foundation IRCCS Policlinico San Matteo, University of Pavia, Pavia, Italy

${ }^{\mathrm{x}}$ Fondazione Policlinico Universitario A. Gemelli - IRCCS - Istituto di Malattie Infettive -Università Cattolica del Sacro Cuore, Livio, Italy
}

\section{A R T I C L E I N F O}

\section{A B S T R A C T}

\section{Keywords:}

Bacterial

\footnotetext{
* Corresponding author at: Stem Cell Transplant Center, AOU Citta' della Salute e della Scienza, Corso Bramante 88, 10126, Turin, Italy.

E-mail addresses: abusca@cittadellasalute.to.it (A. Busca), chiara.cattaneo@asst-spedalicivili.it (C. Cattaneo), elena.decarolis@policlinicogemelli.it (E. De

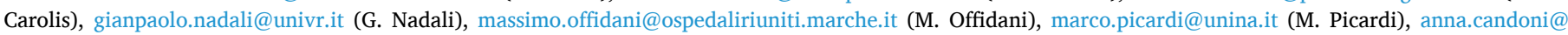

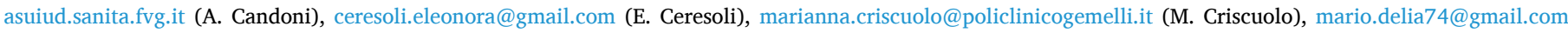

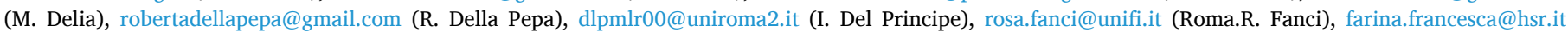

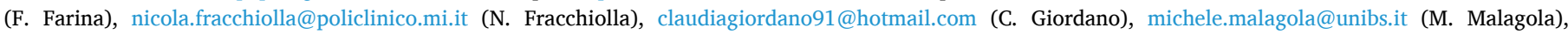

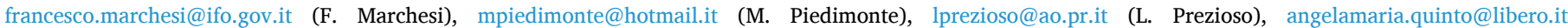

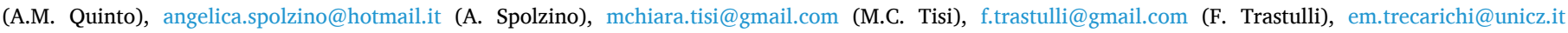
(E.M. Trecarichi), P.Zappasodi@smatteo.pv.it (P. Zappasodi), Mario.tumbarello@unicatt.it (M. Tumbarello), Pagano@unicatt.it (L. Pagano).
} 
Fungal and viral infections Lymphoproliferative disorders Antimicrobial prophylaxis Antimicrobial stewardship.
The therapeutic armamentarium for the treatment of patients with lymphoproliferative diseases has grown considerably over the most recent years, including a large use of new immunotherapeutic agents. As a consequence, the epidemiology of infectious complications in this group of patients is poorly documented, and even more importantly, the potential benefit of antimicrobial prophylaxis remains a matter of debate when considering the harmful effect from the emergence of multidrug resistant pathogens. The present position paper is addressed to all hematologists treating patients affected by lymphoproliferative malignancies with the aim to provide clinicians with a useful tool for the prevention of bacterial, fungal and viral infections.

\section{Introduction}

Infectious complications still represent one of the principal causes of morbidity and mortality for patients with lymphoproliferative diseases (Nørgaard et al., 2006; Di Blasi et al., 2018).

The immunocompromised condition of the host depending on the underlying disease and the severity of neutropenia secondary to the intensity of the chemotherapic regimens are well established risk factors for the development of infections in patients with lymphoproliferative disorders (Nørgaard et al., 2006; Pagano et al., 2017a). On the other hand, monoclonal antibodies targeting neoplastic cells bearing tumor antigens, inhibitors of BCR signaling, immunomodulatory drugs and cellular immunotherapy represent the most recent options for the treatment of patients with lymphoproliferative malignancies (Santos et al., 2017; Mehta-Shah and Younes, 2015). The preliminary results reported with the use of these immunological agents seem to be extremely promising, however, the precise effects of these agents on the adaptive immunity are not yet completely defined. Furthermore, these new treatments are given as single agent or in many circumstances in combination with conventional chemotherapy making the incidence and the management of infectious complications largely unknown.

Aim of present position paper is to provide readers with a reliable platform to guide an optimal anti-infective prophylaxis in patients with lymphoproliferative disorders

\section{Methods}

We conducted a comprehensive electronic literature search from January 2008 to June 2018, using the PubMed database. Only human studies published in English language were included. Our search terms and medical subject headings (MeSH) were: acute lymphoblastic leukemia (ALL) and infections, and/or bacterial, and/or fungal, and/or viral infections; chronic Lymphocytic Leukemia (CLL) and infections, and/or bacterial, and/or fungal, and/or viral infections; Non-Hodgkin lymphoma (NHL) or Hodgkin lymphoma (HL) and infections, and/or bacterial, and/or fungal, and/or viral infections; multiple myeloma (MM) and infections, and/or bacterial, and/or fungal, and/or viral infections.

Results were screened based on titles and abstracts to determine suitability for inclusion in this scoping review. The attention was focused on the epidemiology, risk factors and prophylaxis of bacterial, fungal and viral infections. The evaluation of vaccination programs has not been taken into account in the present review. We considered all studies including controlled clinical trials, prospective and retrospective observational studies including at least ten patients. The proposed management of infectious complications has been highlighted in bold italic at the end of each chapter. The co-authors reviewed all the publications, identified and prepared a slide set comprising evidence-based statements and recommendations presented to the annual SEIFEM (Sorveglianza Epidemiologica delle Infezioni nelle EMopatie group) meeting held in Rome 2019, where experts of infectious complications in hematologic patients convened : after revision according to the results of the discussion, a summary report was made.

\section{Acute lymphoblastic leukemia (ALL)}

Treatment strategies of patients with ALL have changed over the last 10-15 years, with the extension of pediatric or intensive protocols to young and older adults and the introduction of tyrosine kinase inhibitors (TKI) for Philadelphia positive $(\mathrm{Ph}+$ ) ALL. These different therapeutic approaches, and the availability of new immunological drugs, such as monoclonal antibodies, and CD19-targeted chimeric antigen receptor (CAR)-modified $\mathrm{T}$ cell immunotherapy, may be responsible for a different epidemiology of infectious complications. Overall, fatal infections during ALL induction therapy occur in $4.7 \%$ of the patients (Di Blasi et al., 2018), although the incidence is reported to be higher in adults than in children or adolescents, and particularly in the elderly population (Ribera et al., 2008; Rijneveld et al., 2011; Daenen et al., 2012; Sive et al., 2012); the infection related mortality reaches $11.8 \%$ in patients over 60 years treated with an intensive protocol (Martell et al., 2013). On the other hand, a chemotherapy-free approach or a reduced intensity chemotherapy for $\mathrm{Ph}+\mathrm{ALL}$ led to a lower rate of infections (Ribera et al., 2016). The impact of Rituximab (R) on the predisposition to develop infections seems to be controversial: Thomas et al. (Thomas et al., 2010) showed a higher number of infection-related death in complete remission among patients treated with $\mathrm{R}+$ intensified HyperCVAD as compared to an historical control group of patients treated without R; by contrast, Maury et al. (Maury et al., 2016), did not find a significant increase of infections in the $\mathrm{R}$ arm. In a randomized trial for relapsed/refractory ALL, inotuzumab alone was associated with a reduced rate of febrile neutropenia episodes and invasive fungal infection (IFI) as compared to chemotherapy ( $24 \%$ vs $49 \%$ and $0 \%$ vs $2 \%$ respectively) (Kantarjian et al., 2016). However, the association of inotuzumab + reduced intensity chemotherapy as first line therapy in older patients resulted in a $10 \%$ of fatal sepsis and a high incidence of infectious complications (Kantarjian et al., 2018; Jabbour et al., 2018). Similarly, the rate of grade 3-4 infections in patients who received blinatumomab was reduced when compared to the chemotherapy group ( $34.1 \%$ vs $52.3 \%$ ); in particular, $1.5 \%$ and $3 \%$ of IFI were reported in patients treated with blinatumomab and chemotherapy respectively (Kantarjian et al., 2017). Finally, a recent analysis of infectious complications during CAR-T cell immunotherapy in ALL revealed a close association with the presence of severe ( $\geq$ grade 3 ) cytokine release syndrome (CRS), with a $6 \%$ of infection related mortality in a series of 53 adult patients with relapsed/refractory ALL (Park et al., 2018). In this study, the incidence of bacterial, fungal and viral infections within 30 days were $32 \%, 7.5 \%$ and $9.4 \%$, respectively. Similar findings have been reported by Hill et al. (Hill et al., 2018) (25.5\%, $4.5 \%$ and $10.6 \%$ in ALL patients respectively).

\subsection{Bacterial infections}

A large multicenter retrospective study by the SEIFEM group revealed that the rate of bacterial infections in patients with ALL ranged between $18.5 \%$ and $28.5 \%$, according to the different phase of treatment (Di Blasi et al., 2018). Bacterial infections were observed in $34.3 \%$ of the patients during induction in the GRAAL-2005 study, with an infection-related mortality of $2.8 \%$ (Honeyman et al., 2016). Gram-positive bacteremias were predominantly found in the GRAAL-2005 study (Sulis et al., 2018), while gram-negative rods were 
the leading cause of bacteremias in the SEIFEM study (Di Blasi et al., 2018), possibly due to the epidemiology of the different geographic areas in different period of time and the choice of prophylactic regimens.

Studies concerning antibacterial prophylaxis with fluoroquinolones (FQ) in ALL were mostly conducted in pediatric patients receiving intensive chemotherapy (Yousef et al., 2004; Widjajanto et al., 2013; Wolf et al., 2017; Sulis et al., 2018; Alexander et al., 2018); the majority of the studies demonstrated a reduction of febrile episodes, BSI incidence and hospitalization/intensive care unit admission, without a significant increase of multi-resistant bacteria or $C$. difficile infections, and no effect on survival.

Antibacterial prophylaxis in ALL is a matter of debate. it should be considered during induction/reinduction phase of treatment, with $a \geq 7$ days expected severe neutropenia. Close monitoring of bacterial epidemiology should also be done, in order to detect early emerging antibiotic resistant strains.

\subsection{Fungal infections}

Data on IFI in ALL are rather limited: the incidence of IFI was $7.8 \%$ in the GRAAL-2005 series (Mariette et al., 2017), whereas the SEIFEM study (Di Blasi et al., 2018) showed a lower incidence (4.3\%); the prospective randomized AmBiGuard study (Cornely et al., 2017) reported a rate of IFI up to $11.7 \%$ in the placebo group, while a negligible incidence of IFI has been observed in Ph + ALL patients even in elderly patients receiving low-dose chemotherapy regimens + TKI or TKI alone (Chalandon et al., 2015; Foà et al., 2011; Vignetti et al., 2007; Rousselot et al., 2016). Mold infections, particularly Aspergillus spp, were prevalent in adult population (Di Blasi et al., 2018; Cornely et al., 2017): advanced age was a risk factor for IFI (Ribera et al., 2008; Daenen et al., 2012) and IFI-related mortality (Di Blasi et al., 2018), whereas a negligible incidence of IFI has been observed in $\mathrm{Ph}+$ ALL patients receiving low-dose chemotherapy regimens + TKI or TKI alone even in elderly patients (Chalandon et al., 2015; Foà et al., 2011; Vignetti et al., 2007; Rousselot et al., 2016).

Few data on primary antifungal prophylaxis (PAP) in ALL are available. Table 1 summarizes the main studies reporting epidemiologic data on PAP in ALL patients. According to a multicenter retrospective study evaluating PAP vs no PAP (Cattaneo et al., 2011) in ALL, the incidence of IFI (possible/proven/probable), was $2.6 \%$ vs $21 \%$ and similar results have been reported by Cornely et al. in the AmBiGuard study (Cornely et al., 2017) (no PAP vs L-AmB: $11.7 \%$ vs $7.9 \%$, respectively). A recent phase II trial which analyzed the efficacy of micafungin as antifungal prophylaxis in 65 ALL patients, reported a 4.6 $\%$ rate of possible/proven/probable IFI (Park et al., 2019). It is noteworthy that a shift in epidemiology towards non-albicans Candida spp. has been recently observed (Mellinghoff et al., 2018) and surveillance studies aimed to assess antifungal susceptibilities are largely desirable in order to adopt the most appropriate regimen. In addition, prophylaxis of Pneumocystis jirovecii pneumonia (PJP) prophylaxis is universally accepted and recommended by different scientific society guidelines (Cordonnier et al., 2016; Green et al., 2007).

Although further studies should be performed in order to assess the actual risk of IFI in ALL, the current data support the utility of moldactive prophylaxis in ALL, at least in intensive regimen protocols and particularly in older patients. No clear benefit has been demonstrated for echinocandins and polyenes in ALL, but at present they are the only available drugs for ALL patients receiving vinca alkaloids.

Strategies for preventing PJP in ALL during the whole treatment course include trimethoprim/sulfamethoxazole (TMP/SMX); pentamidine by aerosol, atovaquone or dapsone may be considered as acceptable options for TMP/SMX intolerant patients.

\subsection{Viral infections}

Many studies reported a beneficial effect of acyclovir-based prophylaxis in reducing oral mucositis in HSV-seropositive patients (Saral et al., 1983; Bustamante and Wade, 1991). Therefore, antiviral prophylaxis with acyclovir during leukemia induction in HSV-seropositive patients is usually recommended with a moderate/high level of evidence (Styczynski et al., 2009).

Patients with ALL should be screened for HBV infection prior to starting immunosuppressive antineoplastic agents (Reddy et al., 2015; EASL, 2017). Patients with B ALL often receive anthracycline-based regimens and high-dose corticosteroids: consequently, a nucleoside analogue (entecavir $0.5 \mathrm{mg}$ /day or tenofovir $245 \mathrm{mg} /$ day) is employed in patients who are HBsAg positive (HBVreactivation $>10 \%$ ), (Reddy et al., 2015), while lamivudine is preferred in HBsAg-negative/anti-HBc-positive patients (EASL, 2017). When $R$ is part of the chemotherapy regimen, prophylaxis is strongly suggested (entecavir or tenofovir for at least 12 months if HBsAg positive) since patients are considered at high-risk of reactivation (Reddy et al., 2015).

Table 1

Main studies reporting epidemiologic data on PAP in ALL patients.

\begin{tabular}{|c|c|c|c|c|}
\hline References & Type of study & Arms and number of Patients & Overall infection rate & Comments \\
\hline $\begin{array}{l}\text { Cattaneo, } 201 \text { (Nachbaur } \\
\text { et al., 2015) }\end{array}$ & $\begin{array}{l}\text { Prospective, } \\
\text { Phase II (randomized } \\
\text { comparison) }\end{array}$ & $\begin{array}{l}175 \text { AML/ALL (138/37) } \\
\text { Caspofungin (93) vs standard policy (82) }\end{array}$ & $\begin{array}{l}\text { - p/p IFI: } 5.7 \% \text { (AML: } 6.5 \% \text {; } \\
\text { ALL: } 2.7 \% \text { ) } \\
\text { - p/p IFI caspofungin } 7.5 \% \text { vs } \\
\text { SP } 3.7 \%\end{array}$ & $\begin{array}{l}\text { No stratification according to PAP in } \\
\text { ALL }\end{array}$ \\
\hline $\begin{array}{l}\text { Nachbaur, } 2015 \text { ( } \\
\text { Nachbaur et al., 2015) }\end{array}$ & Retrospective & $\begin{array}{l}100 \text { pts with various HM; Micafungin } \\
\text { during neutropenia (ALL } 10 \% \text { ) }\end{array}$ & $\begin{array}{l}\text {-IFI breakthrough: } 6 \% \text { (proven), } \\
3 \% \text { (prob) } \\
\text {-IFI proven: } 4 \text { molds e } 2 \\
\text { Candida }\end{array}$ & $\begin{array}{l}\text { Heterogeneous population and } \\
\text { treatments }\end{array}$ \\
\hline $\begin{array}{l}\text { Koehler, } 2017 \text { (Koehler } \\
\quad \text { et al., 2017) }\end{array}$ & Prospective, observational & $\begin{array}{l}179 \\
\text { AML/ALL ( } 87 \% / 13 \%) \\
\text { Various PAP }\end{array}$ & -IA incidence: $3.8 \%$ & No stratification according to PAP \\
\hline $\begin{array}{l}\text { Nicolato, } 2016 \text { (Nicolato } \\
\text { et al., 2016) }\end{array}$ & Retrospective & $\begin{array}{l}350 \text { febrile episodes in ALL pts } \\
\text { Various PAP ( } 27 \%)\end{array}$ & -IFI prevalence: $8.8 \%$ & $\begin{array}{l}\text { Different type of treatment; analysis } \\
\text { only during neutropenia }\end{array}$ \\
\hline $\begin{array}{l}\text { Doan, } 2016 \text { (Doan et al., } \\
\text { 2016) }\end{array}$ & Retrospective & $\begin{array}{l}98 \text { ALL } \\
\text { (including Ph pos, } 27 \% \text { ) } \\
\text { PAP and no PAP }\end{array}$ & $\begin{array}{l}\text {-IFI: } 11 \% \text { (poss/prov/prob) } \\
\text {-IFI during PAP: } 2.6 \% \\
\text {-IFI no PAP: } 21 \%\end{array}$ & $85 \%$ of pts received PAP \\
\hline $\begin{array}{l}\text { Cornely, } 2017 \text { (Cornely } \\
\text { et al., 2017) }\end{array}$ & $\begin{array}{l}\text { Prospective, randomized } \\
\text { phase III (induction) }\end{array}$ & L-Amb (237) vs placebo (118) & -p/p IFI: $7.9 \%$ vs $11.7 \%$ (NS) & $\begin{array}{l}\text { Heterogeneous chemotherapic } \\
\text { treatments }\end{array}$ \\
\hline $\begin{array}{l}\text { Wang, } 2018 \text { (Wang et al., } \\
\text { 2018) }\end{array}$ & Retrospective & $\begin{array}{l}103 \text { pts } \\
\text { Fluconazole vs mold-active PAP }\end{array}$ & $\begin{array}{l}\text {-IFI } 17.6 \% \text { vs } 15.9 \% \\
\text {-IA fluconazole } 11.8 \% \text { vs mold } \\
\text { active PAP } 1.4 \%\end{array}$ & Real life study, low sample size \\
\hline
\end{tabular}

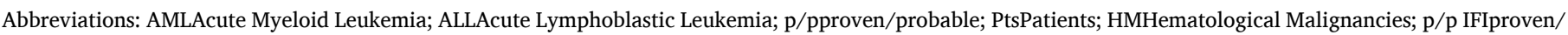
probable Invasive Fungal Infection; IAInvasive Aspergillosis; PAPPrimary Antifungal Prophylaxis; L-AmBLiposomal Amphotericin B. 
Epidemiology of other viral infections is largely underestimated, because of the lack of systematic monitoring of viral infections. In a retrospective Indian study, the incidence of CMV symptomatic reactivation was $11.3 \%$, occurring particularly in the later phases of treatment during high doses of steroids (Gulia et al., 2014). A study from the M.D. Anderson reported the occurrence of CMV pneumonia in $2.5 \%$ of patients with ALL (Nguyen et al., 2001).

Antiviral prophylaxis is not recommended in ALL patients except for HSV prevention with acyclovir in seropositive patients at least during induction treatment. Anti HBV prophylaxis is strongly recommended in ALL patients (entecavir or tenofovir in HbsAg-positive patients and lamivudine in HBsAg-negative/anti-HBc-positive patients (expert opinion).

\section{Chronic lymphocytic leukemia}

The main risk factors of infection in patients with CLL include several immune defects (e.g. abnormal complement-dependent cytotoxicity, qualitative deficiencies of neutrophil function etc.) related to the disease and the use of immunosuppressive treatments (Forconi and Moss, 2015).

Disease-related defects include hypogammaglobulinemia, which occurs in virtually all patients with CLL and correlates with duration and stage of the disease (Wadhwa and Morrison, 2006; Ravandi and O'Brien, 2006). Quantitative and qualitative neutrophil and monocyte defects are found in CLL patients and although the absolute number of neutrophils is normal or slightly decreased in untreated patients, defects in phagocytic and bactericidal activity, have been demonstrated in a consistent number of subjects (Wadhwa and Morrison, 2006). Major infections occur in $>50 \%$ of CLL patients contributing to $30 \%-50 \%$ of deaths (Moreira et al., 2013; Morrison et al., 2001; Hensel et al., 2003). In addition to alkylating agents, purine analogues and monoclonal antibodies that have been used for the treatment of CLL for many years, new classes of highly effective drugs have been introduced in the clinical practice. These compounds act by inhibiting the Bruton Tyrosine Kinase (BTK) or the phosphatidylinositol 3-kinase (PI3K), key components of the B-cell receptor (BCR) signaling pathway, through which the growth, adhesion and survival of B cells are regulated (Tillman et al., 2018). The BTK is also present in neutrophils, monocytes and macrophages where it mediates pathways involving innate and adaptive immunity (Tillman et al., 2018). Therefore, the molecular targets of these agents are also found in normal cells and can be involved in the exertion of several deleterious off-target effects (de Weerdt et al., 2017).

\subsection{Bacterial infections}

The abnormal complement activity occurring in patients with CLL, may predispose patients to infections due to the lack of protection normally ensured by the opsonization process and subsequent neutrophil activation. Staphylococcus aureus and various gram-negative pathogens such as Pseudomonas aeruginosa, Escherichia coli and Klebsiella pneumoniae may cause infections during neutropenia and in patients with severe hypogammaglobulinemia (Nosari, 2012). Several studies showed a high rate of infections, mainly bacterial (18 \%-36 \%) in patients treated with fludarabine-cyclophosphamide (FC) alone or in combination with R (Joffe et al., 2018; Guillermin et al., 2018; Eichhorst et al., 2016; Strati et al., 2013; Tam Constantine et al., 2008), probably due to the severe and long-lasting T-cell depletion. Bacterial infections after FCR are common in patients older than 65 years (Eichhorst et al., 2016) and with absolute lymphocyte counts $\leq 1.0 \times 10^{3}$ cells $/ \mu \mathrm{L}$ at 3 months after FCR (21.0 \% vs $13.8 \%$ ) (Joffe et al., 2018). Overall, the infection risk is higher during the first year after therapy and rapidly declines to less than $1.5 \%$ per year from the third year onward. Treatment with bendamustine monotherapy or in combination with $\mathrm{R}$ was less clearly associated with infections. Chlorambucil-treated patients, alone or in association with ofatumumab, show a very low infection rate ranging between 2 and 9\% (Michallet et al., 2018; Knauf et al., 2009;
Hillmen et al., 2015; Burger et al., 2015). Overall, the infection rate ranged from 11 to $14 \%$ when chlorambucil was combined with $\mathrm{R}$ or obinutuzumab and the majority of the infections are reported of bacterial origin (Goede et al., 2014). The reported risk of infections following treatment with Ibrutinib or other BTK inhibitors, alone or in combination with other agents, ranges from 11,4\%-29\% (Varughese et al., 2018; Chanan-Khan et al., 2016; Burger et al., 2014; Byrd et al., 2014; Reinwald et al., 2018; Kim et al., 2008b) and only 5\% have a bacterial origin. Most frequent adverse events reported in randomized trials with idelalisib, alone or in combination with other drugs, are pneumonia, pyrexia, and febrile neutropenia (Jones et al., 2017a; Zelenetz et al., 2017; Brown et al., 2014; Furman et al., 2014), but data on microbial aetiology are not always available. Table 2 reports the most relevant studies on bacterial infections in patients with CLL.

Specific antibacterial prophylaxis may not be recommended in patients with CLL, although FQ prophylaxis may be considered in FCR and BR regimes. Monitoring of local epidemiology should be considered mandatory to guide appropriate antibiotic treatment.

\subsection{Fungal infections}

The incidence of fungal infections in CLL patients ranges between 0.5-18\% (Varughese et al., 2018; Williams et al., 2018; Nosari et al., 2014; Pagano et al., 2017b, a; Safdar et al., 2010; Stanzani et al., 2013; Sun et al., 2015; Teng et al., 2015; Tisi et al., 2017; Visentin et al., 2017; Francis et al., 2006) according to the treatment received and Aspergillus $s p p$. is the most frequently isolated fungal pathogen (Raisch et al., 2016). Interestingly, CLL with an unfavorable prognostic profile were more often affected by IFI. In particular, CD38 expression, genetic profile (p53, ATM or 12+) and IgvH mutation status represented biological risk factors for IFI (Pagano et al., 2017b; Nosari et al., 2014, 2014; Pagano et al., 2017b, a; Safdar et al., 2010; Stanzani et al., 2013; Sun et al., 2015; Teng et al., 2015; Tisi et al., 2017; Visentin et al., 2017; Francis et al., 2006). Five cases with PCR-evidence of PJP were found in a cohort of 96 patients (Ahn et al., 2016). An open label trial comparing idelalisib and ofatumumab versus ofatumumab monotherapy in patients with relapsed CLL reported a PJP rate of 5\% vs. 1\% (Jones et al., 2017b). A retrospective analysis of 8 studies (front line/relapsed CLL and relapsed iNHL) included 2198 patients who received idelalisib alone or with $\mathrm{R}$ or bendamustine- $\mathrm{R}(\mathrm{BR})$ and patients treated with $\mathrm{R} \pm$ bendamustine: the overall incidence of PJP infection was $2.5 \%$ in patients receiving idelalisib \pm combination therapy vs $0.2 \%$ in patients receiving only $R$ alone or BR alone (relative risk $=12.5$ ) (Sehn et al., 2016).

At present, data available are not sufficient to expect benefit from universal use of antifungal prophylaxis, but as the indications for ibrutinib continue to expand, there is the need for further studies defining those patients who are candidates for close clinical monitoring and/or mold-active prophylaxis strategies. PJP prophylaxis is recommended for all patients receiving idelalisib for a period of 2-6 months after discontinuation of the treatment,

\subsection{Viral infections}

Viral infections are a relevant cause of morbidity in CLL patients (Merchardt et al., 2013). The incidence of CMV infections in CLL patients ranges between 0 and $46 \%$, according to the treatment received and the diagnostic strategy used for virus detection (Merchardt et al., 2013; Marchesi et al., 2018) (Table 3). While the treatment with fludarabine, bendamustine and $\mathrm{R}$ was not clearly associated with CMV reactivation (Chan et al., 2015; Munõz et al., 2014), recent data reported several cases of CMV infection following administration of idelalisib, with an estimated incidence of about $2 \%$ (Reinwald et al., 2018; Jones et al., 2017a; Ljungman et al., 2017). A very low rate of HSV and VZV infections has been reported in patients treated with chlorambucil, $\mathrm{R}$ and BCR inhibitors, while fludarabine should be considered as the most relevant risk factor for these viral infections (Table 3). 
Table 2

Infection in Chronic Lymphocytic Leukemia (CLL). Clinical studies and other relevant recent references about bacterial infections published since 2008.

\begin{tabular}{|c|c|c|c|c|}
\hline Reference & Type of study & Arms and number of patients & $\begin{array}{l}\text { Overall } \\
\text { infection rate }\end{array}$ & Comments \\
\hline $\begin{array}{l}\text { Varughese, } 2018 \text { ( } \\
\text { Varughese et al., } \\
\text { 2018) }\end{array}$ & Retrospective & $\begin{array}{l}\text { Ibrutinib } \\
\text { CLL } 165 \text { pts (as 1st-line treatment: } 33 \% \\
\text { and as monotherapy: } 95 \% \text { ) }\end{array}$ & $12 \%$ & $\begin{array}{l}\text { Bacterial infections: } 5 \%(9 / 165) \text {. Staphylococcus aureus is the most } \\
\text { common bacterial pathogen identified. Among the cases of bacterial } \\
\text { infection were } 10 \text { cases of pulmonary or pleural space infections and } 7 \\
\text { of bloodstream infection. }\end{array}$ \\
\hline $\begin{array}{l}\text { Michallet, } 2018 \text { ( } \\
\text { Michallet et al., 2018) }\end{array}$ & $\begin{array}{l}\text { Prospective, } \\
\text { phase III }\end{array}$ & $\begin{array}{l}\text { R-Benda vs R- CLB in Fluda-ineligible CLL } \\
\text { pts } \\
357 \text { pts }\end{array}$ & $19 \%$ vs $8 \%$ & $\begin{array}{l}\text { Bacterial infections: data not available. Febrile neutropenia: } 6 \% \text { vs } 4 \% \text {. } \\
\text { Any infection were significantly more frequent with R-Benda than with } \\
\text { R-CLB. }\end{array}$ \\
\hline $\begin{array}{l}\text { Joffe, } 2018 \text { (Joffe et al., } \\
\text { 2018) }\end{array}$ & Retrospective & FCR frontline, 99 pts & NA & $\begin{array}{l}\text { For bacterial infections evaluable } 92 \text { pts. Bacterial infections: } 18,7 \% \text {. } \\
\text { Bacterial infections after FCR based on ALC levels at } 3 \text { months were } \\
\text { significantly more frequent if ALC levels } \leq 1.0 \times 10^{3} \text { cells } / \mu \mathrm{L}(21.0 \% \text { vs } \\
13.8 \%) \text { (p .596). }\end{array}$ \\
\hline $\begin{array}{l}\text { Guillermin, } 2017 \text { ( } \\
\text { Guillermin et al., } \\
\text { 2018) }\end{array}$ & Retrospective & $\begin{array}{l}\text { FC-based first-line treatment }(79 \% \\
\text { FCR);76 pts }\end{array}$ & $16.4 \%$ & Bacterial infections (any grade): $35.9 \%$ \\
\hline $\begin{array}{l}\text { Jones, } 2017 \text { (Jones et al., } \\
\text { 2017a) }\end{array}$ & $\begin{array}{l}\text { Prospective, } \\
\text { Phase III }\end{array}$ & Idela + O vs O in R/R CLL; 261 pts & NA & $\begin{array}{l}\text { Higher incidence of severe infection in the idela group: pneumonia (13 } \\
\% \text { vs } 10 \% \text { ) and sepsis ( } 6 \% \text { vs } 1 \% \text { ) }\end{array}$ \\
\hline $\begin{array}{l}\text { Eichhorst, } 2016 \text { ( } \\
\text { Eichhorst et al., 2016) }\end{array}$ & $\begin{array}{l}\text { Prospective, } \\
\text { Phase III }\end{array}$ & $\begin{array}{l}\text { FCR vs R-Benda in TN advanced CLL } \\
561 \text { pts }\end{array}$ & $\begin{array}{l}39 \% \text { vs } 25 \% \\
\text { (grade } \geq 3 \text { ) }\end{array}$ & $\begin{array}{l}\text { The incidence of bacterial infections (grade } 3 \text { and } 4 \text { ) between treatment } \\
\text { group was similar: } 2 \% \text {. Increased frequency of severe infection in FCR } \\
\text { arm and in older than } 65 \text { years. }\end{array}$ \\
\hline $\begin{array}{l}\text { Zelenetz, } 2017 \text { (Zelenetz } \\
\text { et al., 2017) }\end{array}$ & $\begin{array}{l}\text { Prospective, } \\
\text { Phase III }\end{array}$ & $\begin{array}{l}\text { Idela vs placebo in combination with R- } \\
\text { Benda in R/R CLL; } 416 \text { pts }\end{array}$ & $\begin{array}{l}39 \% \text { vs } 25 \% \\
\text { (grade } \geq 3 \text { ) }\end{array}$ & $\begin{array}{l}\text { Bacterial Infections: data not available. The frequency of infections was } \\
\text { higher in the idela group than in the placebo group and most infections } \\
\text { such as pneumonia and upper respiratory tract infections were bacterial } \\
\text { (data on rate not shown) }\end{array}$ \\
\hline $\begin{array}{l}\text { Chanan-Khan, } 2016 \text { ( } \\
\text { Chanan-Khan et al., } \\
\text { 2016) }\end{array}$ & $\begin{array}{l}\text { Prospective, } \\
\text { Phase III }\end{array}$ & $\begin{array}{l}\text { IBRU vs placebo in combination with R- } \\
\text { Benda in R/R CLL } 578 \text { pts }\end{array}$ & $\begin{array}{l}29 \% \text { vs } 25 \% \\
\text { (grade } \geq 3 \text { ) }\end{array}$ & Bacterial Infections: data not available \\
\hline $\begin{array}{l}\text { Hillmen, } 2015 \text { (Hillmen } \\
\text { et al., 2015) }\end{array}$ & $\begin{array}{l}\text { Prosepctive, } \\
\text { Phase III }\end{array}$ & $\begin{array}{l}\text { CLB vs O-CLB } \\
447 \text { pts }\end{array}$ & $\begin{array}{l}9 \% \text { vs } 12 \% \\
\text { (grade } \geq 3 \text { ) }\end{array}$ & $\begin{array}{l}\text { The most common infections were respiratory tract infections. } 27 \% \text { vs } \\
31 \% \text {. Similar frequencies of sepsis ( } 3 \% \text { O-CLB vs } 2 \% \text { CLB). Bacterial } \\
\text { Infections: data not available }\end{array}$ \\
\hline $\begin{array}{l}\text { Burger, } 2015 \text { (Burger } \\
\text { et al., 2015) }\end{array}$ & $\begin{array}{l}\text { Prosepctive, } \\
\text { Phase III }\end{array}$ & $\begin{array}{l}\text { CLB vs IBRU frontline } \\
\text { CLL } 269 \text { pts }\end{array}$ & $2 \%$ & Bacterial Infections: data not available \\
\hline $\begin{array}{l}\text { Goede, } 2014 \text { (Goede } \\
\text { et al., 2014) }\end{array}$ & $\begin{array}{l}\text { Prosepctive, } \\
\text { Phase III }\end{array}$ & $\begin{array}{l}\text { G-CLB or R-CLB vs CLB in TN CLL with } \\
\text { comorbidities; } 781 \text { pts }\end{array}$ & $\begin{array}{l}11 \%-14 \% \\
\text { (grade } \geq 3 \text { ) }\end{array}$ & $\begin{array}{l}\text { Bacterial Infections: data not available. Most reported infections were of } \\
\text { bacterial origin (data on rate not shown) }\end{array}$ \\
\hline $\begin{array}{l}\text { Burger, } 2014 \text { (Burger } \\
\text { et al., 2014) }\end{array}$ & $\begin{array}{l}\text { Prosepctive, } \\
\text { Phase II }\end{array}$ & R- IBRU in High-risk CLL; 40 pts & $\begin{array}{l}13 \% \\
\text { (grade } \geq 3 \text { ) }\end{array}$ & $\begin{array}{l}\text { Bacterial Infections: data not available. There were: two lung infections, } \\
\text { one upper respiratory tract infection, one sepsis, and one mucositis. }\end{array}$ \\
\hline $\begin{array}{l}\text { Byrd, } 2014 \text { (Byrd et al., } \\
\text { 2014) }\end{array}$ & $\begin{array}{l}\text { Prosepctive, } \\
\text { Phase III }\end{array}$ & IBRU vs O in R/R CLL/SLL; 391 pts & $\begin{array}{l}24 \% \text { vs } 22 \% \\
\text { (grade } \geq 3 \text { ) }\end{array}$ & $\begin{array}{l}\text { Bacterial Infections: data not available. There were: pneumonia, } \\
\text { including Pseudomonas aeruginosa, Urinary tract infection, Cellulitis, } \\
\text { Stenotrophomonas ae. infection and Sepsis }\end{array}$ \\
\hline $\begin{array}{l}\text { Strati, } 2013 \text { (Strati et al., } \\
\text { 2013) }\end{array}$ & Retrospective & $\begin{array}{l}\text { FCR frontline } \\
\text { Total } 207 \text { pts : } 72 \text { cytopenic at } 3 \text { months, } \\
45 \text { cytopenic at } 6 \text { months and } 24 \\
\text { cytopenic at } 9 \text { months }\end{array}$ & $\begin{array}{l}21 \%(15 / 72) \\
22 \%(10 / 45) \\
38 \%(9 / 24)\end{array}$ & $\begin{array}{l}\text { This study compares pts with and without cytopenia after frontline FCR. } \\
\text { Late infections were more common in patients who were cytopenic at } 9 \\
\text { months ( } 38 \% \text { ) and were mostly bacterial ( } 6 \text { pts- } 67 \% \text { ). No differences in } \\
\text { infection rates were reported when patients who were cytopenic at any } \\
\text { time were compared with patients who were noncytopenic at any time }\end{array}$ \\
\hline $\begin{array}{l}\text { Knauf, } 2009 \text { (Knauf } \\
\text { et al., 2009) }\end{array}$ & $\begin{array}{l}\text { Prosepctive, } \\
\text { Phase III }\end{array}$ & $\begin{array}{l}\text { Benda vs CLB in TN advanced CLL; } 319 \\
\text { pts }\end{array}$ & $8 \%$ vs $3 \%$ & $\begin{array}{l}\text { Infections occurring during Benda treatment may be related to transient } \\
\text { neutropenia, and are prevalently bacterial (data on rate not shown) }\end{array}$ \\
\hline $\begin{array}{l}\text { Tam, } 2008 \text { (Tam } \\
\text { Constantine et al., } \\
\text { 2008) }\end{array}$ & $\begin{array}{l}\text { Prosepctive, } \\
\text { Phase II }\end{array}$ & $\begin{array}{l}\text { FCR frontline } \\
224 \text { pts }\end{array}$ & NA & $\begin{array}{l}\text { The risk of late infection was } 10 \% \text { and } 4 \% \text { for the first and second years } \\
\text { of remission, respectively, and less than } 1.5 \% \text { per year for the third year } \\
\text { onward. From the third year predominantly bacterial infection (data on } \\
\text { rate not shown) }\end{array}$ \\
\hline
\end{tabular}

Abbreviations: Pts: patients; R: Rituximab; CLB: chlorambucil; Fluda: Fludarabine; Benda: Bendamustine, IBRU: Ibrutinib; Idela: Idelalisib; O Ofatumumab; G (GA101): obinutuzumab; FCR: fludarabine, cyclophosphamide, and rituximab; FC: fludarabine, cyclophosphamide; TN and R/R CLL: treatment-naive and relapsed/ refractory chronic lymphocytic leukemia; SLL: small lymphocytic lymphoma ALC: absolute lymphocyte count.

HBsAg-positive patients with CLL and indolent lymphomas who receive treatments based on $\mathrm{R}$ or obinotuzumab, in association with bendamustine, fludarabine or cyclophosfamide should receive entecavir $0.5 \mathrm{mg}$ /day or tenofovir $245 \mathrm{mg}$ /day for at least 12 months after discontinuation of immunosuppressive therapy (Reddy et al., 2015), while lamivudine $100 \mathrm{mg} /$ day is recommended in $\mathrm{HBsAg}$ negative/anti-HBc-positive patients (expert opinion) (41). A warning from EMA PRAC was issued in June 2017 for a risk of $<1 \%$ for HBV reactivation in patients receiving ibrutinib. The recommendation is to monitor and manage according to local medical standards of care.

Finally, some cases of progressive multifocal leuco-encephalopathy (PML) caused by $J C$ virus have been reported in CLL patients treated with BCR inhibitors (Reinwald et al., 2018). Clinicians should be aware of this severe viral complication, even though risk factors and treatment are not known so far.

A specific antiviral prophylaxis against CMV is not recommended in CLL patients treated with Fludarabine, bendamustine and rituximab.
Due to the emergence of CMV infections in patients treated with idelalisib, there is a strong recommendation to monitor patients with a PCRbased diagnostic strategy for CMV reactivation.

\section{Lymphomas}

Conventional chemotherapy leading to profound neutropenia represents the risk factor for infectious complications in patients with lymphomas. Monoclonal antibodies, namely R, obinotuzumab and brentuximab-vedotin, alter immune response by modulating B-/T-cell interactions rather than directly affecting humoral immunity (Podhorecka et al., 2014). In addition, B-cell depletion exerts a deleterious impact on the induction, maintenance and activation of cell-mediated immunity (Nosari et al., 2014; Teng et al., 2015; Podhorecka et al., 2014). Table 4, reports the main studies analyzing infectious complications in patients receiving therapy for NHL and HL. 
Table 3

Viral infections in Chronic Lymphocytic Leukemia (CLL).

\begin{tabular}{|c|c|c|c|c|}
\hline Reference & Type of study & $\begin{array}{l}\text { Arm and } \\
\text { number of patients }\end{array}$ & $\begin{array}{l}\text { CMV Infection } \\
\text { rate }\end{array}$ & Comments \\
\hline $\begin{array}{l}\text { Demitrovicova, } 2017 \text { ( } \\
\text { Demitrovicova et al., 2017) }\end{array}$ & Retrospective & $\begin{array}{l}\text { Fluda, ALZ, } \\
\text { Bendamustine, BCRi } \\
110 \text { pts }\end{array}$ & $8.14 \%$ & $\begin{array}{l}\text { Lower risk of infectious complications in patients treated with novel targeted } \\
\text { agents }\end{array}$ \\
\hline Jones, 2017 & Randomized & $\begin{array}{l}\text { Idela }+ \text { Ofa } v s \text { Idela } 201 \\
\text { pts }\end{array}$ & $2 \%$ & Higher rate of infections in patients treated with Ofa + Idela including CMV \\
\hline Ghiridhar et al., 2017 & Case report & BCRi 2 pts & - & $\begin{array}{l}\text { Disseminated VZV in two patients treated with BCRi (Idelalisib and Ibrutinib). } \\
\text { None of these patients received antiviral prophylaxis }\end{array}$ \\
\hline Sutton, 2016 & Case report & None $1 \mathrm{pt}$ & - & $\begin{array}{l}\text { Disseminated VZV in a patient with severe hypogammaglobulinemia. No specific } \\
\text { treatment for CLL }\end{array}$ \\
\hline Chan, 2015 & Retrospective & $\begin{array}{l}\text { Fluda plus Rituximab } \\
138 \text { pts }\end{array}$ & $\begin{array}{l}3.6 \% \\
\text { (CMV } \\
\text { retinitis) }\end{array}$ & $\begin{array}{l}\text { Five cases of CMV retinitis. Treatment was based both on intravitreal and } \\
\text { systemic Ganciclovir and Foscarnet }\end{array}$ \\
\hline Munõz, 2014 & Retrospective & $\begin{array}{l}\text { Rituximab plus } \\
\text { Bendamustine } \\
18 \text { pts(*) }\end{array}$ & $5.5 \%$ & Once case of asymptomatic CMV reactivation detected by PCR \\
\hline Freedberg, 2013 & Case report & Fluda $1 \mathrm{pt}$ & - & $\begin{array}{l}\text { First case of visceral VZV infection in a patient with CLL treated with } \\
\text { Fluda. No antiviral prophylaxis was given }\end{array}$ \\
\hline
\end{tabular}

Abbreviations: Pts: patients; CMV: Cytomegalovirus; Fluda: Fludarabine; ALZ: Alemtuzumab; BCRi: B-cell receptor inhibitors; Idela: Idelalisib; Ofa: Ofatumumab; CLL: chronic lymphocytic leukemia; PCR: polymerase-chain reaction; VZV: Varicella Zoster virus; HSV: Herpes simplex virus.

\subsection{Bacterial infections}

Bucaneve et al, and Cullen et al. (Bucaneve et al., 2005; Cullen et al., 2005) demonstrated in randomized, double blind studies including NHL patients, that antibacterial prophylaxis with levofloxacin was effective in reducing infection rate, but not mortality.

(Gafter-Gvili et al. (2016)) reported that $34.6 \%$ of 153 NHL patients who received bendamustine developed infections, resulting in a higher mortality when compared to non-infected patients (22\% vs. $8 \%$ ). Antibacterial prophylaxis policy was not reported.

Varughese et al. (Varughese et al., 2018) found a 7\% rate of bacterial infections in patients treated with ibrutinib for B-cell NHL, mostly due to gram-positive bacteria ( $48 \%$ ): main risk factors were the number of prior therapeutic lines $>3$ and neutropenia, occurring in $2 \%$ of NHL patients. In patients with refractory or relapsed follicular lymphoma, idelalisib was associated with a non-negligible incidence of fever (35\%), neutropenia (24\%) and upper respiratory infections (21.6\%), but a low rate of pneumonitis (3\%) associated with a prevalence of gram-positive bacteria (Salles et al., 2017). The ESCMID 2018 guidelines do not recommend antibiotic prophylaxis in patients treated with ibrutinib or idelalisib (Reinwald et al., 2018).

Obinutuzumab seems to be associated with a higher incidence of febrile neutropenia and infections as compared to R (Byrd et al., 2014). Brentuximab-vedotin is associated to $55 \%$ incidence of infections when combined with AVD (adriamycin, vinblastine and dacarbazine) regimen (Drgona et al., 2018; Connors et al., 2017) while the combination with bendamustine resulted in a $14 \%$ rate of grade 3 lung infection and $25 \%$ rate of grade 3-4 neutropenia (O'Connor et al., 2018). There are very few data about adaptive immunotherapy with CAR-T cells. Hill JA et al. evaluated 62 patients who received CAR-T cells for relapsed/refractory NHL, showing a $9.7 \%$ incidence of bacterial infections, mostly gram-positive bacteria thereby supporting anti-gram positive prophylaxis with levofloxacin (Hill et al., 2018).

Bacterial prophylaxis should be tailored on an individual basis, considering multiple variables: type of disease (HL, NHL); biological characteristics (indolent vs aggressive); treatment strategy, including conventional chemotherapy with lymphodepleting agents, platinumbased regimens, dose escalated schedules, immunotherapy, number of previous lines of treatment. It should be underscored that antibacterial prophylaxis does not have a clearly demonstrated impact on attributable mortality to infection, while the issue of resistant strains selection is an emerging aspect. A new field of investigation is represented by patients who received adaptive immunotherapy with CD 19-targeted chimeric antigen receptor T cells (CAR-T), in whom prophylaxis with levofloxacin
$750 \mathrm{mg} /$ day is recommended in the case of ANC $<500 / \mathrm{mm}^{3}$.

\subsection{Fungal infections}

Several studies raised concern that the BTK inhibitor ibrutinib may increase the risk for IFI. In this respect, different mechanisms by which ibrunitib may favor the occurrence of IFI have been described, including impaired function of alveolar macrophage, neutrophil, T-cell, and platelets as well as alterations in the chemotaxis and cytokine environment. According to these findings, a recent study analyzing ibrutinib treatment for primary CNS lymphoma reported a $39 \%$ rate of invasive aspergillosis in patients concurrently receiving steroids even in the absence of neutropenia, while others studies have reported a lower incidence of IFI around 3-4\% (Carson et al., 2014). Conversely, the risk of IFI with the use of idelalisib, seems to be restricted to PJP only; accordingly, the ESCMID 2018 guidelines recommend prophylaxis for PJP until 2-6 months after discontinuation of idelalisib (Reinwald et al., 2018). Very few clinical data on IFI are available regarding patients treated with different strategies such as CD30-targeted agents and obinotuzumab. Preliminary data have been recently reported on adaptive immunotherapy with CAR-T cells (Hill et al., 2018). All categories of infectious complications initially occurred after a median of 6 days from CAR-T cell infusion; fungal infections were recorded in $4.8 \%$ of NHL patients.

In the case of first-line antineoplastic therapy with $\mathrm{R}-\mathrm{CHOP}$ or ABVD regimens no antifungal prophylaxis is recommended. In the case of further line of treatment TMP/SMX is recommended in patients with $\mathrm{HL}>60$ years old until 2-6 months after chemotherapy discontinuation, while Fluconazole is used in patients with NHL. Mold-active antifungal prophylaxis is not recommended in patients receiving ibrutinib or idelalisib (Wang et al., 2018). PJP prophylaxis is mandatory in patients treated with Brentuximab-vedotin (expert opinion) as consolidation or salvage therapy following ASCT, as well as in patients treated with idelalisib. Based on the preliminary results of the CAR-T cells studies, immunoglobulin repletion and antifungal prophylaxis are needed for these high-risk patients.

\subsection{Viral infections}

According to the 2015 guidelines of the American Gastroenterological Association (AGA) Institute, immunosuppressants are categorized into low-, moderate-, or high-risk groups based on estimates of HBV reactivation $(\mathrm{HBVr})$ as per available evidence. Among patients with aggressive B lymphomas, the high-risk group (incidence of $\mathrm{HBVr}>10 \%$ ) 
Table 4

Studies analyzing infections in patients with NHL.

\begin{tabular}{|c|c|c|c|c|}
\hline \multicolumn{5}{|l|}{ FUNGAL INFECTIONS } \\
\hline Reference & Type of study & $\begin{array}{l}\text { Arms and number of } \\
\text { patients }\end{array}$ & Overall infection Rate & Comments \\
\hline \multicolumn{5}{|l|}{$\begin{array}{l}\text { Cytotoxic agent-based } \\
\text { antineoplastic } \\
\text { therapy }\end{array}$} \\
\hline $\begin{array}{l}\text { Wongso, } 2013 \text { (Wongso } \\
\text { et al., 2013) }\end{array}$ & $\begin{array}{l}\text { Retrospective } \\
\text { multicentric }\end{array}$ & $\begin{array}{l}3402 \text { patients (advanced- } \\
\text { stage classic } \mathrm{HL} \text { ) } \\
\text { BEACOPP escalated } \\
124 \text { patients (refractory/ }\end{array}$ & $\begin{array}{l}0.35 \%(12 / 3402 \text { cases }) \\
\text { PJP, candidiasis, IA }\end{array}$ & $\begin{array}{l}\text { TMP-SMZ in patients with HL }>60 \text { years until } 2-6 \\
\text { months after chemotherapy discontinuation }\end{array}$ \\
\hline $\begin{array}{l}\text { Takaoka, } 2014 \text { (Takaoka } \\
\text { et al., 2014) }\end{array}$ & $\begin{array}{l}\text { Retrospective } \\
\text { monocentric }\end{array}$ & $\begin{array}{l}\text { relapsed NHL) } \\
\text { Salvage therapy with } \\
\text { ESHAP, VIM or MPV } \\
638 \text { patients, NHL } 450\end{array}$ & $\begin{array}{l}12.9 \% \text { Proven/Probable IFI } \\
\text { (16/124 cases) }\end{array}$ & Fluconazole 400 mg PO/IV daily \\
\hline $\begin{array}{l}\text { Tisi, } 2017 \text { (Tisi et al., } \\
\text { 2017) }\end{array}$ & $\begin{array}{l}\text { Retrospective } \\
\text { monocentric }\end{array}$ & $\begin{array}{l}(70.5 \%) \text {, HL } 188 \text { (29.5 } \\
\text { R-CHOP, ABVD }\end{array}$ & $\begin{array}{l}2.5 \% \text { Proven/Probable IA (16/ } \\
638 \text { cases); } 2.2 \% \text { in NHL; } 3.2 \% \\
\text { in HL }\end{array}$ & No prophylaxis recommended \\
\hline \multicolumn{5}{|l|}{$\begin{array}{l}\text { Small-Molecule } \\
\text { Inhibitors }\end{array}$} \\
\hline $\begin{array}{l}\text { Varughese, } 2018 \text { ( } \\
\text { Varughese et al., 2018) }\end{array}$ & Retrospective & 213 NHL; Ibrutinib & $\begin{array}{l}2.8 \%(6 / 213 \text { cases }) \\
\text { IA } 2 \text { cases, } \\
\text { PJP } 2 \text { cases, } \\
\text { IA + PJP } 1 \text { case, } \\
\text { cryptococcosis } 1 \text { case }\end{array}$ & \\
\hline $\begin{array}{l}\text { Cheah, } 2016 \text { (Cheah and } \\
\text { Fowler, 2016) }\end{array}$ & Review & NA; Idelalisib & IFI $<1 \%$ & $\begin{array}{l}\text { PJP prophylaxis during treatment. Interrupt idelalisib } \\
\text { when PJP is suspected and discontinue when confirmed }\end{array}$ \\
\hline \multicolumn{5}{|l|}{$\begin{array}{l}\text { Engineering immune } \\
\text { cells }\end{array}$} \\
\hline $\begin{array}{l}\text { Hill, } 2018 \text { (Hill et al., } \\
\text { 2018) }\end{array}$ & $\begin{array}{l}\text { Open-label single- } \\
\text { institution }\end{array}$ & $62 \mathrm{NHL} ; \mathrm{CAR}-\mathrm{T}$ & $4.8 \%(3 / 62$ cases $)$ & $\begin{array}{l}\text { Immunoglobulin repletion; antifungal prophylaxis for } \\
\text { high-risk patients }\end{array}$ \\
\hline \multicolumn{5}{|l|}{$\begin{array}{l}\text { BACTERIAL } \\
\text { INFECTIONS }\end{array}$} \\
\hline $\begin{array}{l}\text { Reference } \\
\text { Cytotoxic agent-based } \\
\text { antineoplastic } \\
\text { therapy }\end{array}$ & Type of study & Arms and No. patients & Rate of infection & Comments \\
\hline $\begin{array}{l}\text { Dendle, } 2017 \text { (Dendle } \\
\text { et al., 2017) }\end{array}$ & $\begin{array}{l}\text { Retrospective } \\
\text { Monocentric }\end{array}$ & 325 DLBCL, R-CHOP & $\begin{array}{l}15.3 \%(50 / 325) \\
\text { Gram-neg, } 39 \text { cases; } \\
\text { Gram-pos, } 11 \text { cases }\end{array}$ & $\begin{array}{l}\text { Recommend primary prophylaxis with G-CSF in } \\
\text { patients older than } 65 \text { years and/or with comorbidities. } \\
\text { No antibiotic prophylaxis is recommended }\end{array}$ \\
\hline $\begin{array}{l}\text { Gafter-Gvili, } 2016 \text { ( } \\
\text { Gafter-Gvili et al., } \\
\text { 2016) }\end{array}$ & $\begin{array}{l}\text { Retrospective } \\
\text { multicentric }\end{array}$ & 153 NHL, Bendamustine & $7.8 \%$ of BSI $(12 / 153)$ & No antibiotic prophylaxis is recommended \\
\hline \multicolumn{5}{|l|}{$\begin{array}{l}\text { Small-Molecule } \\
\text { Inhibitors }\end{array}$} \\
\hline $\begin{array}{l}\text { Salles., } 2017 \text { (Salles } \\
\quad \text { et al., 2017) }\end{array}$ & $\begin{array}{l}\text { Retrospective } \\
\text { monocentric }\end{array}$ & $125 \mathrm{~F}$ L, Idelalisib & $\begin{array}{l}2.4 \%(3 / 125 \text { g-pos }) \\
7 \%(14 / 213)\end{array}$ & No antibiotic or GCSF prophylaxis is recommended \\
\hline $\begin{array}{l}\text { Varughese, } 2018 \text { ( } \\
\text { Varughese et al., 2018) }\end{array}$ & $\begin{array}{l}\text { Retrospective } \\
\text { monocentric }\end{array}$ & 213 NHL, Ibrutinib & $\begin{array}{l}\text { Gram-pos, } 7 \text { cases; } \\
\text { Gram-neg, } 5 \text { cases; } \\
\text { Other, } 2 \text { cases }\end{array}$ & No antibiotic or G-CSF prophylaxis is recommended \\
\hline \multicolumn{5}{|l|}{$\begin{array}{l}\text { Engineering immune } \\
\text { cells }\end{array}$} \\
\hline $\begin{array}{l}\text { Hill JA, } 2018 \text { (Hill et al., } \\
\text { 2018) }\end{array}$ & $\begin{array}{l}\text { Open-label single- } \\
\text { institution }\end{array}$ & 62 NHL CAR-T & $\begin{array}{l}9.7 \%(6 / 62) \\
\text { Gram-pos, } 3 \text { cases; } \\
\text { Gram-neg, } 2 \text { cases; } \\
\text { Mycoplasma, } 1 \text { case }\end{array}$ & $\begin{array}{l}\text { Prophylaxis with Levofloxacin } 750 \mathrm{mg} / \text { die if } \\
\text { ANC }<500 / \mathrm{m}^{3}\end{array}$ \\
\hline $\begin{array}{l}\text { VIRAL INFECTIONS } \\
\text { Reference } \\
\text { Cytotoxic agent-based } \\
\text { antineoplastic } \\
\text { therapy }\end{array}$ & Type of study & Arms and No. patients & Overall infection rate & Comments \\
\hline $\begin{array}{l}\text { Reddy., } 2015 \text { (Reddy } \\
\text { et al., 2015) }\end{array}$ & Guidelines & $\begin{array}{l}60 \text { patients with DLBCL } \\
\text { and } \\
\text { HBsAg + in prophylaxis } \\
\text { with lamivudine } \\
\text { R-CHOP } \\
39 \text { patients with NHL and }\end{array}$ & $30 \%(18 / 60)$ & $\begin{array}{l}\text { Prophylaxis with Entecavir } 0.5 \mathrm{mg} \text { die for at least } 6 \\
\text { months after discontinuation of immunosuppressive } \\
\text { therapy. }\end{array}$ \\
\hline $\begin{array}{l}\text { Reddy., } 2015 \text { (Reddy } \\
\text { et al., 2015) }\end{array}$ & Guidelines & $\begin{array}{l}\text { HBcAb + with no antiviral } \\
\text { prophylaxis } \\
\text { R-CHOP }\end{array}$ & $18 \%(7 / 39)$ & $\begin{array}{l}\text { Prophylaxis with Entecavir } 0.5 \mathrm{mg} \text { per os/ die for at } \\
\text { least } 6 \text { months after discontinuation of } \\
\text { immunosuppressive therapy }\end{array}$ \\
\hline $\begin{array}{l}\text { Chung, } 2015 \text { (Chung } \\
\text { et al., 2015) }\end{array}$ & Guidelines & $\begin{array}{l}131 \text { patients with LNH } \\
\text { HCV+, R-CHOP, R-CEOP }\end{array}$ & $27 \%(36 / 131)$ & $\begin{array}{l}\text { Treat HCV-infected patients with antiviral therapy with } \\
\text { the goal of achieving SVR before chemotherapy }\end{array}$ \\
\hline
\end{tabular}


Table 4 (continued)

\begin{tabular}{|c|c|c|c|c|}
\hline FUNGAL INFECTIONS & & & & \\
\hline $\begin{array}{l}\text { Cho, } 2015 \text { (Cho et al., } \\
\text { 2015) }\end{array}$ & $\begin{array}{l}\text { Nation wide population- } \\
\text { based study }\end{array}$ & $\begin{array}{l}1677 \text { NHL, R-CHOP/ } \\
\text { RCEOP }\end{array}$ & & $\begin{array}{l}\text { Prophylaxis against herpes zoster might be considered } \\
\text { in pts undergoing immune-chemotherapy }\end{array}$ \\
\hline \multicolumn{5}{|l|}{$\begin{array}{l}\text { Small molecules } \\
\text { inhibitor }\end{array}$} \\
\hline $\begin{array}{l}\text { Cheah, } 2016 \text { (Cheah and } \\
\text { Fowler, 2016) }\end{array}$ & Review & $\begin{array}{l}\text { NA } \\
\text { Idelalisib }\end{array}$ & $<1 \%$ CMV infection & $\begin{array}{l}\text { If seropositive regular clinical or laboratory monitoring } \\
\text { is mandatory. } \\
\text { If symptomatic infection: stop idelalisib and preemptive } \\
\text { ganciclovir. }\end{array}$ \\
\hline $\begin{array}{l}\text { Raisch D., } 2016 \text { (Raisch } \\
\text { et al., 2016) }\end{array}$ & $\begin{array}{l}\text { FDA's adverse event } \\
\text { reporting system of PML. } \\
\text { Case Report }\end{array}$ & Ibrutinib & $\begin{array}{l}0.35 \%(10 / 2860 \text { total AE per } \\
\text { drug) }\end{array}$ & $\begin{array}{l}\text { New-onset signs and symptoms of central nervous } \\
\text { system abnormalities: } \\
\text { Consultation with a neurologist, brain MRI, and lumbar } \\
\text { puncture. }\end{array}$ \\
\hline \multicolumn{5}{|l|}{$\begin{array}{l}\text { Engineering immune } \\
\text { cell }\end{array}$} \\
\hline & & $\begin{array}{l}133 \text { Relapsed/Refractory } \\
\text { CD19+ ALL, CLL, or NH }\end{array}$ & $9 \%(13 / 133)$ & \\
\hline $\begin{array}{l}\text { Hill, } 2018 \text { (Hill et al., } \\
\text { 2018) }\end{array}$ & Prospective & CAR T Cell & $\begin{array}{l}\text { Rhinovirus: } 4 \text {; Parainfluenza: } 3 \\
\text { Influenza A: } 1 \text {; } \\
\text { Metapneumovirus: } 1 \\
\text { Coronavirus: } 1 \text {; CMV viremia:1 } \\
\text { EBV viremia: } 1 \text {; EBV in } \\
\text { cerebrospinal fluid of unclear } \\
\text { clinical significance, } \mathrm{n}=1\end{array}$ & $\begin{array}{l}\text { Patients with greater immunosuppression and CAR-T } \\
\text { cell associated toxicities had the highest risk for } \\
\text { infection, identifying a targeted group to study } \\
\text { improved prophylactic strategy. }\end{array}$ \\
\hline \multicolumn{5}{|l|}{$\begin{array}{l}\text { Other agents targeting } \\
\text { lymphoid cell } \\
\text { surface antigens }\end{array}$} \\
\hline $\begin{array}{l}\text { Gopal, } 2012 \text { (Gopal } \\
\text { et al., 2012) }\end{array}$ & $\begin{array}{l}\text { open-label, } \\
\text { nonrandomized } \\
\text { multicenter trials. }\end{array}$ & $\begin{array}{l}25 \text { Relapsed HL CD30+ } \\
\text { Brentuximab }\end{array}$ & $0.2 \%(5 / 25) \mathrm{CMV}$ & $\begin{array}{l}\text { Monitor periodically CMV viremia especially with a } \\
\text { positive or unknown history of CMV serology or } \\
\text { viremia. }\end{array}$ \\
\hline $\begin{array}{l}\text { Raisch, } 2016 \text { (Raisch } \\
\text { et al., 2016) }\end{array}$ & $\begin{array}{l}\text { FDA's adverse event } \\
\text { reporting system of PML. } \\
\text { Case Report }\end{array}$ & $\begin{array}{l}\text { NA } \\
\text { Obinutuzumab/ } \\
\text { Brentuximab }\end{array}$ & $\begin{array}{l}\text { Obinutuzumab: } 3 / 655 \text { total } \mathrm{AE} \\
0.46 \% \\
\text { Brentuximab: } 15 / 1017 \text { total } \mathrm{AE} \\
1.47 \%\end{array}$ & $\begin{array}{l}\text { New onset signs and symptoms of central nervous } \\
\text { system abnormalities. Consultation with e neurologist, } \\
\text { brain MRI and lumbar punction }\end{array}$ \\
\hline
\end{tabular}

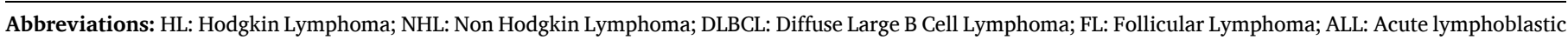

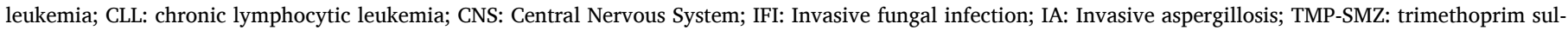
famethoxazole.

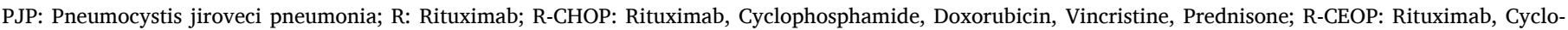

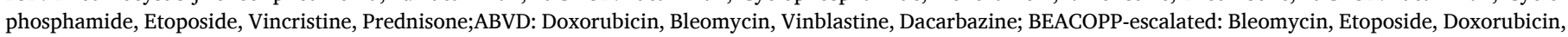

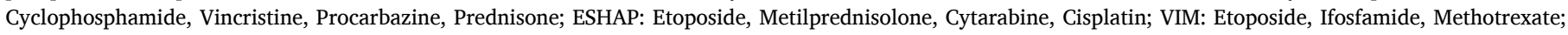

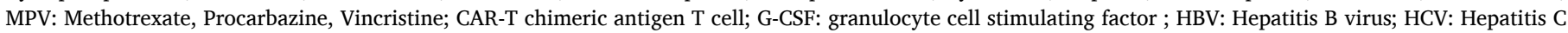

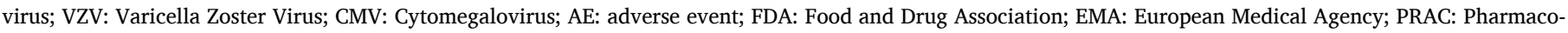
vigilance Risk Assessment Committee; AE: adverse Event.

consists of the following: B cell depleting treatments in either HBsAgpositive and HBsAg-negative/anti-HBc-positive patients, anthracycline-based treatments in HBsAg-positive patients, and HBsAgpositive patients receiving prednisone at a dose $>20 \mathrm{mg}$ /day for 4 weeks. HBsAg-positive patients with lymphoma receiving anti-CD30 agents such as brentuximab are also included in the high-risk group. The moderate-risk group (incidence of $\mathrm{HBVr} 1-10 \%$ ) includes $\mathrm{HBsAg}$ negative/anti-HBc-positive patients receiving prednisone at moderateor high- dose and anthracycline derivatives. For the high-risk group with HBsAg positivity, antiviral prophylaxis (entecavir, $0.5 \mathrm{mg}$ /day; or tenofovir disoproxil fumarate $245 \mathrm{mg}$ /day) is recommended for at least 6 months after discontinuation of immunosuppressive therapy (at least 12 months for B cell-depleting agents) (Reddy et al., 2015). According to the European Association for the Study of the Liver (EASL) guidelines (version 2017) (EASL, 2017), lamivudine prophylaxis (100 mg/day) is preferred in HBsAg negative/anti-HBc-positive patients.

CMV reactivation is a possible complication in patients receiving brentuximab-vedotin therapy, especially if combined with bendamustine. In a prospective clinical trial in relapsed HL, CMV reactivation rate was $0.2 \%$ and was potentially clinically significant in only 1 patient (O'Connor et al., 2018).

Fatal cases of JC virus infection resulting in PML have been reported for brentuximab treatment ( $1.47 \%$ of total adverse events), and for obinotuzumab (0.49\% of total adverse events) (Carson et al., 2014;
Raisch et al., 2016).

As regards to CAR-T cell, Hill et al. found that viral infections were extremely common, with 13 infections in 133 patients (Rhinovirus: 4 cases; Parainfluenza: 3; Influenza A: 1; Metapneumovirus: 1; Coronavirus: 1; CMV viremia: 1 ; EBV viremia: 1 ; EBV in cerebrospinal fluid of unclear clinical significance: 1 ), although the rate was similar to that of patients with relapsed/refractory B-cell lymphoma undergoing immunechemotherapy (Hill et al., 2018). Patients treated with nivolumab and pembrolizumab for relapsed/refractory HL and NHL do not have an increased risk of viral infection (Redelman-Sidi et al., 2018).

Prophylaxis against VZV might be considered in patients receiving conventional chemotherapy (Expert opinion). We recommend for CMV seropositive patients in treatment with idelalisib to perform regular PCR monitoring of DNA (Expert opinion). Idelalisib should be discontinued and ganciclovir/valganciclovir preemptively initiated in patients with positive CMV PCR and symptoms consistent with CMV infection.

Any patient receiving brentuximab presenting new-onset signs and symptoms of CNS abnormalities should hold treatment for any suspected case of PML and discontinue if a diagnosis of PML is confirmed (neurologist consultation, brain MRI, and lumbar puncture recommended). 


\section{Multiple Myeloma (MM)}

Over the last ten years, therapeutic options for patients with MM have largely increased. Nowadays, the use of new generation immunomodulatory drugs (IMiDs) and proteasome inhibitors (PIs) in induction and maintenance of transplant eligible and ineligible patients have modified the natural history of the disease, as well as the introduction of monoclonal antibodies (MoAb) alone or in combination with IMiDs/PIs in patients with relapse/refractory (R/R) MM. Due to the humoral and cellular immune deficit, infections are among the leading causes of death in MM.

In 2015, a population-based study (Blimark et al., 2015) compared the risk of infection between patients with MM and sex-, age-, country residence-matched controls from total population registry; the authors reported an overall risk of infection 7 times higher in patients with MM, with a risk 11 times higher during the first year after diagnosis. Moreover, the risk of infection has increased 2.9-fold from 1988 to 1993 to $2000-2004$, with a cumulative risk at 5 years growing from $14.4 \%-46 \%$.

Two meta-analyses have been recently published, evaluating the impact of IMiDs or PIs on the development of infections in patients with MM at different phases of treatment (Chen et al., 2018; Teh et al., 2016). In newly diagnosed MM patients who were eligible for autologous stem cell transplantation (ASCT), the risk of severe infections during first line therapy with thalidomide was up to $14.8 \%$. Comparing patients treated with thalidomide versus lenalidomide, the incidence of severe infections was $11.7 \%$ and $12.3 \%$, respectively, in transplant ineligible patients, and $10.7 \%$ and $8.2 \%$, respectively, during maintenance. Among R/R patients, the highest incidence of severe infections was reported with pomalidomide (23\%). (Chen et al., 2018). Among patients treated with PI-based induction, the incidence of severe infection was $9.7 \%$ and 19.7 $\%$ in transplant ineligible and eligible patients, respectively, and up to $23 \%$ for all grade infections (Teh et al., 2016).

Two clinical trials investigated the role of ASCT in the setting of lenalidomide-based treatment. (Palumbo et al. (2014)), compared ASCT with melphalan-prednisone-lenalidomide (MPR) consolidation, showing a significant higher incidence of grade 3-4 infection in the ASCT arm compared with MPR arm (16.3\% vs0.8 \%, p=0.001). Similarly, (Attal et al. (2017)) reported a significant higher incidence of severe infections among transplant recipients compared to patients receiving lenalidomide, bortezomib and dexamethasone (VRD) as consolidation $(20 \%$ vs $9 \%)$. A recent retrospective study evaluated the incidence of infections in patients treated with daratumumab-containing regimens: the rate of infections ranged from $26 \%$ to $56 \%$ when daratumumab was used as single agent or combined with other agents (Johnsrud et al., 2020 e). Fig. 1 shows a schematic representation of anti-infective prophylaxis in patients with MM.

\subsection{Bacterial infections}

Bacteria were found to be the main agent responsible for infectious complications in several studies including patients with MM (Blimark et al., 2015; Teh et al., 2015). In a population-based study including 1154 patients diagnosed from 2010 to 2013 and treated with novel agents, the peak of incidence of bloodstream infections (BSI) was within the first 6 months from MM diagnosis and risk factors of BSI were markers for aggressive disease, namely ISS-III and high LDH (Sørrig et al., 2018). The early occurrence of BSI have been confirmed by other studies, showing an incidence of BSI of $11.7 \%$ within 3 months from diagnosis of MM with the highest rate at 4-6 months from the diagnosis (Teh et al., 2015; Huang et al., 2017). In the FIRST trial comparing lenalidomide plus dexamethasone (Rd) continuous $v s$ MPT or Rd18 in 1623 transplant-ineligible patients, the number of grade $\geq 3$ infection$\mathrm{s} /$ month was highest during the first 4 months of treatment. Moreover, $75 \%$ of all grade $\geq 3$ infections occurred in the absence of neutropenia and the development of early severe infections was an independent risk factor for death (Dumontet et al., 2018). Moreover, in patients with MM a near 8-fold increased risk ( $\mathrm{HR}=7.7$ ) of developing bacterial pneumonia compared to matched controls (Redelman-Sidi et al., 2018) was reported.

The role of antibiotic prophylaxis in preventing the incidence of bacterial infections during MM treatment has been investigated in several studies (Oken et al., 1996; Vesole et al., 2012; Jung et al., 2014).

Oken et al. ((Oken et al., 1996)) compared a group of 28 patients randomly assigned to PJP prophylaxis with TMP-SMX for 2 months after the start of chemotherapy with a control group of 26 patients who did not receive any prophylaxis, documenting a significant lower rate of bacterial infection during the 3-month study period (2.43 per patient-year for controls $v s 0.29$ per patient-year for the TMP-SMX group). However, a further study of the same group comparing three groups of MM patients receiving initial chemotherapy randomized on a 1:1:1 basis to daily ciprofloxacin, TMP-SMX or no prophylaxis, failed to demonstrate any difference in incidence of serious bacterial infections during the first 2 months from induction chemotherapy (Vesole et al., 2012). More recently, (Jung et al. (2014)) analyzed the incidence of severe infections in a cohort of $80 \mathrm{MM}$ patients receiving prophylaxis with levofloxacin after bortezomib-based regimens compared to an historical control group $(n=139)$ of patients who did not receive prophylaxis: the results of the study showed a significant decrease in the rate of severe infections in the prophylactic group (17.5\%) compared to the control group (30.9 \%) (Ribera et al., 2016). Interestingly, a

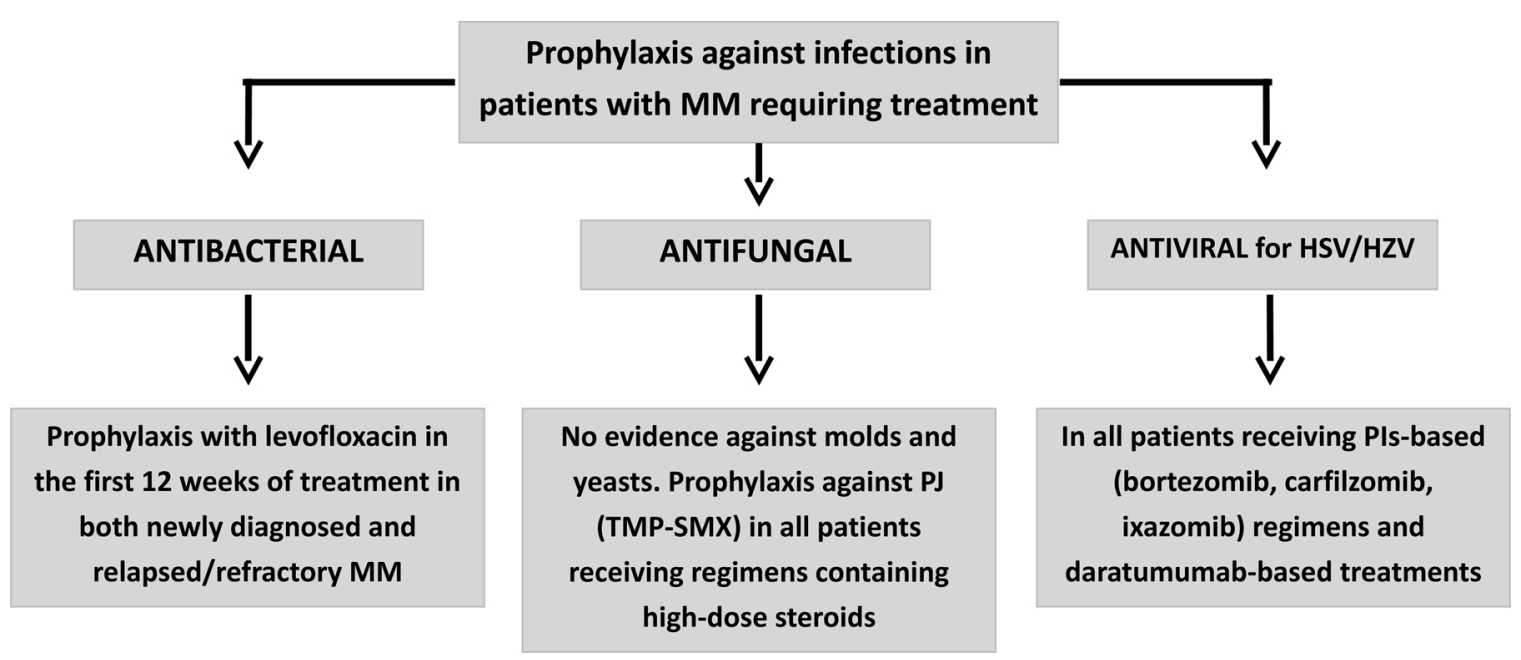

Fig. 1. Proposal of anti-infective prophylaxis in patients receiving treatment for Multiple Myeloma (MM). 
randomized, double-blind, placebo-controlled multi-center phase III clinical trial assessing the benefits of prophylaxis with levofloxacin in 977 newly diagnosed MM patients (Tackling EArly Morbidity and Mortality in Myeloma, TEAMM), demonstrated that levofloxacin prophylaxis significantly reduced the rate of febrile episodes and deaths within the first 12 weeks of treatment, without significant difference between the 2 arms for carriage or infection with Clostridium difficile, methicillin-resistant Staphylococcus aureus and ESBL-producing Gram-negative bacteria (Drayson et al., 2017).

The role of intravenous immunoglobulin supplementation (IVIG) during induction or transplantation is not fully elucidated. Two randomized trials reported a significant benefit from infusion of IVIG on severe and life-threatening infections during chemotherapy (Chapel et al., 1994; Musto et al., 1995). A meta-analysis published in 2009 confirmed the protective role of IVIG in preventing severe infections (Raanani et al., 2009). On the other hand, two recent studies investigating the use of IVIG in the peri-transplant period failed to show a significant reduction of overall rate of infection in patients treated with IVIG compared to placebo (Blombery et al., 2011; Park et al., 2015).

The risk of infection in patients with MM is high regardless of neutropenia, especially in the first 3-4 months of induction therapy, and infection is still the number one cause of death for these patients particularly in older patients. Community acquired pneumonia are the most frequent clinically documented infections. FQ-based prophylaxis during the first 12 weeks of induction, particularly in older patients and in those with high burden of disease, is recommended, although definitive data are still lacking.

\subsection{Fungal infections}

Few studies evaluated the epidemiology of fungal infections in patients with MM. Kurosawa et al. reported an incidence of proven/ probable IFI of $0.8 \%$, similar to the rate reported by Pagano et al. (0.5 $\%$ ), while Huang et al. observed a remarkable higher incidence around $12 \%$ (Kurosawa et al., 2012; Pagano et al., 2006b; Huang et al., 2009). The study by Teh et al. suggested a direct correlation between the number of therapy lines and the risk of IFI, which increases up to $15 \%$ after three or more lines of treatment: the study did not show an increased incidence of IFI with the administration of pomalidomide, carfilzomib or monoclonal antibodies as elotuzumab and daratumumab (Johnsrud et al., 2020 e). MM patients, particularly those receiving high-dose corticosteroids, are at high risk of $P$.jirovecii pneumonia (PJP) (Mellinghoff et al., 2018). The literature reported some cases of PJP in patients receiving bortezomib suggesting that failure of host cell apoptosis caused by the PI may facilitate the infection (Swan and Reid, 2014).

The use of TMP-SMZ prophylaxis against P. jirovecii is mostly recommended among MM patients who receive high dose corticosteroids. There is currently no strong evidence to support PJP prophylaxis in patients with MM receiving PIs as single agent. Due to the low rate of invasive fungal infection in patients with MM, routinely antifungal prophylaxis is not recommended.

\subsection{Viral infections}

The introduction of bortezomib to standard therapies was associated to an increased risk of VZV infections from 4 to $22 \%$ in randomized and retrospective clinical trials (RCT) (San Miguel et al., 2008; Chanan-Khan et al., 2008; Kim et al., 2008a). However, the introduction of antiviral prophylaxis reduced the incidence of VZV infections to less than $1 \%$ (Palumbo et al., 2010). In patients receiving lenalidomide-based regimens, particularly Rd, the incidence of VZV infection ranges from less than 1\%-4\% (Dumontet et al., 2018; Caravita et al., 2012) (Table 5). A recent observational prospective study described a VZV reactivation in $8.5 \%$ of patients during induction therapy and $21.5 \%$ after ASCT, peaking at 8 months from chemotherapy (Kamber et al., 2015). Patients
Table 5

Summary of Key Points for antimicrobial prophylaxis in patients with lymphoproliferative diseases.

\begin{tabular}{cl}
\hline & FQ prophylaxis should be considered during induction/ \\
Acute lymphoblastic & reinduction phase of treatment, although monitoring of \\
leukemia & bacterial epidemiology should be done, in order to \\
detect early emerging antibiotic resistant strains & Antifungal prophylaxis should be considered at least in \\
& patients \\
& receiving intensive regimen protocols and particularly in \\
& older patients. \\
& Patients receiving idelalisib should receive PJP \\
prophylaxis as well as patients receiving fludarabine \\
based chemotherapy \\
There is a strong recommendation to carefully monitor \\
patients receiving idelalisib, with a prospective PCR- \\
based diagnostic strategy for CMV reactivation \\
PJP prophylaxis is recommended in patients $>60$ years \\
until 2-6 months after chemotherapy discontinuation, \\
in particular in patients treated with brentuximab- \\
vedotin as consolidation or salvage therapy following \\
Lymphocytic \\
stem cell transplantation \\
FQ-based prophylaxis is recommended during the first \\
12 weeks of \\
induction, particularly in older patients and in those \\
with high burden of disease
\end{tabular}

Abbreviations: FQ: fluoroquinolones; PJP: Pneumocystis jirovecii pneumonia CMV: Cytomegalovirus;

receiving MoAb as elotuzumab and daratumumab in combination with IMIDs or PIs have a rate of VZV reactivation ranging from $2 \%$ to $5 \%$ even during antiviral prophylaxis.

Patients with MM are at high risk of CMV reactivation during the post ASCT period and during disease progression. Respiratory viral infections are common with the use of combination therapies and may occur throughout the year (Chen et al., 2018), especially in patients with progressive disease and those receiving more than 3 lines of therapy (The et al., 2015). MM patients should be screened for HBV serology and categorized into the high- or moderate- or low-risk score based on the type of serum positivity (Reddy et al., 2015). Patients HBsAg-positive receiving anthracycline and/or steroids should be treated with an anti-nucleoside at high genetic barrier (entecavir or tenofovir) for at least 6 months following antineoplastic treatment as prophylaxis, while HBsAg negative/anti-HBc-positive patients should receive lamivudine for at least 6 months. HBsAg-positive patients treated with bortezomib have a HBVr risk of 1-10\% (moderate-risk group) and require prophylaxis with lamivudine for at least 6 months after discontinuation of immunosuppressive therapy (EASL, 2017).

Acyclovir or valacyclovir prophylaxis is recommended to reduce viral-related morbidity and should be used during the treatment with PIs and after ASCT for 6-12 months after the end of the therapy. In the setting of multiple lines of therapy with associated CD4 lymphopenia, monitoring for CMV viremia should be considered.

\section{Conclusions}

Large studies are needed to assess the epidemiology of infectious complications in patients with lymphoproliferative diseases receiving targeted therapies. Based on these studies, we will be able to select patients who may benefit from anti-infective prophylaxis.

The role of FQ prophylaxis in patients with lymphoproliferative diseases receiving high-dose immuno-chemotherapy is still a matter of debate and prospective randomized trials seem to be necessary to assess whether the potential beneficial effect of prophylaxis is offset by the emergence of MDR bacteria.

Mold active antifungal prophylaxis is not routinely indicated in patients with lymphoproliferative disorders except for patients receiving intensive chemotherapy regimens for the treatment of ALL. PJP prophylaxis is indicated in patients with lymphoproliferative disorders. 
Table 6 summarizes the closing remarks.

\section{Declaration of Competing Interest}

A.B. has received honoraria from Gilead Sciences, MSD, Pfizer Pharmaceuticals and Jazz Pharmaceuticals; he has been speaker for Gilead Sciences, Merck, Pfizer Pharmaceuticals and Novartis; he is part of an Advisory Board of GILEAD and Pfizer; M.O. Has received honoraria from Celgene, Janssen, Amgen, BMS, Takeda; A.C. Has received honoraria from Celgene, Janssen, Gilead, Pfizer and MSD; M.D. Has received honoraria from Gilead, Pfizer and MSD; N. F. Has received honoraria from Gilead, Pfizer, MSD and Amgen; M. M. is part of an Advisory Board of Biotest; F. M. Has received honoraria from MSD; he is part of an Advisory Board of Sandoz and Pfizer; L.P. was Board member of Gilead Science, MSD, Pfizer, Basilea, Janssen, Novartis,Cidara and has been speaker for Gilead Sciences, MSD, Pfizer Pharmaceuticals, Astellas Pharma. C.C., E.D.C., G.N., M.P., E.C., M.C., R.D.P., I.D.P.,R.F., F.F., C. G., M.P., L.P., A.M.Q., A.S., M.C.T., F.T., E.M. T., P.Z., declared nothing to disclose.

\section{References}

Ahn, I.E., Jerussi, T., Farooqui, M., Tian, X., Wiestner, A., Gea-Banacloche, J., 2016. Atypical Pneumocystis jirovecii pneumonia in previously untreated patients with CLL on single-agent ibrutinib. Blood. 128 (October 15), 1940-1943.

Alexander, S., Fisher, B.T., Gaur, A.H., Dvorak, C.C., Villa Luna, D., Dang, H., et al., 2018 Children's oncology group. Effect of levofloxacin prophylaxis on bacteremia in children with acute leukemia or undergoing hematopoietic stem cell transplantation: a randomized clinical trial. JAMA 320 (10), 995-1004.

Attal, M., Lauwers Cances, V., Hulin, C., Leleu, X., Caillot, D., Escoffre, M., et al., 2017. Lenalidomide, Bortezomib, and dexamethasone with transplantation for myeloma. N. Engl. J. Med. 376 (14), 1311-1320.

Blimark, C., Holmberg, E., Mellqvist, U.H., Landgren, O., Björkholm, M., Hultcrantz, M., Kjellander, C., Turesson, I., Kristinsson, S.Y., 2015. Multiple myeloma and infections: a population-based study on 9253 multiple myeloma patients. Haematologica. 100 (1), 107-113.

Blombery, P., Miles Prince, H., Worth, L.J., Main, J., Yang, M., Wood, E.M., Westerman, D.A., 2011. Prophylactic intravenous immunoglobulin during autologous haemopoietic stem cell transplantation for multiple myeloma is not associated with reduced infectious complications. Ann. Hematol. 90 (10), $1167-1172$.

Brown, J.R., Byrd, J.C., Coutre, S.E., Benson, D.M., Flinn, I.W., Wagner-Johnston, N.D., et al., 2014. Idelalisib, an inhibitor of phosphatidylinositol 3-kinase p110delta, for relapsed/refractory chronic lymphocytic leukemia. Blood 123, 3390-3397.

Bucaneve, et al., 2005. Levofloxacin to prevent bacterial infection in patients with cancer and neutropenia. N. Engl. J. Med. 353 (September 10), 977-987.

Burger, J.A., Keating, M.J., Wierda, W.G., Hartmann, E., Hoellenriegel, J., Rosin Nathalie, Y., et al., 2014. Safety and activity of ibrutinib plus rituximab for patients with high-risk chronic lymphocytic leukaemia: a single-arm, phase 2 study. Lancet Oncol. 15, 1090-1099.

Burger, J.A., Tedeschi, A., Barr, P.M., Robak, T., Owen, C., Ghia, P., et al., 2015. Ibrutinib as initial therapy for patients with chronic lymphocytic leukemia. N. Engl. J. Med. 373, 2425-2437.

Bustamante, C.I., Wade, J.C., 1991. Herpes simplex virus infection in the immunocompromised cancer patient. J. Clin. Oncol. 9, 1903-1915.

Byrd, J.C., Brown, J.R., O’Brien, S., Barrientos, J.C., Kay, N.E., Reddy, N.M., et al., 2014. Ibrutinib versus ofatumumab in previously treated chronic lymphoid leukemia. N. Engl. J. Med. 371, 213-223.

Caravita, T., Offidani, M., Siniscalchi, A., Gentili, S., Caraffa, P., Perrotti, A., et al., 2012. Infection complications in an unselected cohort of patients with multiple myeloma treated with lenalidomide combinations. Eur. J. Haematol. 89 (3), 276-277.

Carson, K.R., Newsome, S.D., Kim, E.J., et al., 2014. Progressive multifical leukoencephalopathy associate with brentuximab vedotin therapy: a report of 5 cases from the Southern Network on adverse reactions (SONAR) project. Cancer 16, 2464-2471.

Cattaneo, C., Monte, S., Algarotti, A., Audisio, E., Borlenghi, E., Campiotti, L., et al., 2011. A randomized comparison of caspofungin versus antifungal prophylaxis according to investigator policy in acute leukaemia patients undergoing induction chemotherapy (PROFIL-C study). J. Antimicrob. Chemother. 66 (9), 2140-2145.

Chalandon, Y., Thomas, X., Hayette, S., Cayuela, J.M., Abbal, C., Huguet, F., et al., 2015. Randomized study of reduced-intensity chemotherapy combined with imatinib in adults with Ph-positive acute lymphoblastic leukemia. Blood 125 (24), 3711-3719.

Chan, T.S., Cheung, C.Y., Yeung, I.Y., Hwang, Y.Y., Gill, H., Wong, I.Y., et al., 2015. Cytomegalovirus retinitis complicating combination therapy with Rituximab and Fludarabine. Ann. Hematol. 94, 1043-1047.

Chanan-Khan, A., Sonneveld, P., Schuster, M.W., Stadtmauer, E.A., Facon, T., Harousseau, J.L., et al., 2008. Analysis of herpes zoster events among bortezomibtreated patients in the phase III APEX study. J. Clin. Oncol. 26 (October 29), 4784-4790.
Chanan-Khan, A., Cramer, P., Demirkan, F., Fraser, G., Silva, R.S., Grosicki, S., et al., 2016. Ibrutinib combinedvwith bendamustine and rituximab compared with placebo, bendamustine, and rituximab for previouslyvtreated chronic lymphocytic leukaemia or small lymphocytic lymphoma (HELIOS): a randomised, doubleblind, phase 3 study. Lancet Oncol. 17, 200-211.

Chapel, H.M., Lee, M., Hargreaves, R., Pamphilon, D.H., Prentice, A.G., 1994. Randomised trial of intravenous immunoglobulin as prophylaxis against infection in plateau-phase multiple myeloma. The UK Group for Immunoglobulin Replacement Therapy in Multiple Myeloma. Lancet 343 (8905), 1059-1063.

Cheah, C.Y., Fowler, N.H., 2016. Idelalisib in the management of lymphoma. Blood. https://doi.org/10.1182/blood-2016-02-702761.

Chen, M., Zhao, Y., Xu, C., Wang, X., Zhang, X., Mao, B., 2018. Immunomodulatory drugs and the risk of serious infection in multiple myeloma: systematic review and metaanalysis of randomized and observational studies. Ann. Hematol. 97 (6), 925-944.

Cho, S.-F., Wu, W.-H., Yang, Y.-H., et al., 2015. Longitudinal risk of herpes zoster in patients with non-Hodgkin lymphoma receiving chemotherapy: a nationwide population-based study. Sci. Rep. 14008.

Chung, R., Davis, G., Jensen, D., et al., 2015. Hepatitis C Guidance: AASLD-IDSA reccomendations for testing, managing and treating adults infected with hepatitis $\mathrm{C}$ virus. Hepatology 62 (3), 932-954.

Connors, J.M., et al., 2017. Brentuximab vedotin with chemotherapy for stage III or IV hodgkin's lymphoma. N. Engl. J. Med. https://doi.org/10.1056/NEJMoa1708984.

Cordonnier, C., Cesaro, S., Maschmeyer, G., Einsele, H., Donnelly, J.P., Alanio, A., et al., 2016. Pneumocystis jirovecii pneumonia: still a concern in patients with haematological malignancies and stem cell transplant recipients. J. Antimicrob. Chemother. 71 (9), 2379-2385.

Cornely, O.A., Leguay, T., Maertens, J., MJGT, Vehreschild, Anagnostopoulos, A., Castagnola, C., et al., 2017. Randomized comparison of liposomal amphotericin B versus placebo to prevent invasive mycoses in acute lymphoblastic leukaemia. J. Antimicrob. Chemother. 72 (8), 2359-2367.

Cullen, et al., 2005. Antibacterial prophylaxis after chemotherapy for solid tumors and lymphomas. N. Engl. J. Med. 353 (September 10), 988-998.

Daenen, S., van der Holt, B., Dekker, A.W., Willemze, R., Rijneveld, A.W., Biemond, B.J., et al., 2012. Intensive chemotherapy to improve outcome in patients with acute lymphoblastic leukemia over the age of 40: a phase II study for efficacy and feasibility by HOVON. Leukemia 26 (7), 1726-1729.

de Weerdt, I., Koopmans, S.M., Kater, A.P., van Gelder, M., 2017. Incidence and management of toxicity associated with ibrutinib and idelalisib: a practical approach. Haematologica 102 (October 10), 1629-1639.

Demitrovicova, L., Mikuskova, E., Oraucova, I., Cingelova, S., Drgona, L., Mladosievicova, B., 2017. Infectious complications in chronic lymphocytic leukemia - a retrospective analysis: single center experience. Neoplasma 64, 474-481.

Dendle, C., Gilbertson, M., Spelman, T., et al., 2017. Infection is an independent predictor of death in diffuse large B cell lymphoma. Sci. Rep. 7 (June 1), 4395. https://doi.org/10.1038/s41598-017-04495-x.

Di Blasi, R., Cattaneo, C., Lewis, R.E., Tumbarello, M., Angelici, L., Dragonetti, G., et al., 2018. On the behalf of the SEIFEM group (Sorveglianza Epidemiologica Infezioni Fungine in Ematologia). Febrile events in acute lymphoblastic leukemia: a prospective observational multicentric SEIFEM study (SEIFEM-2012/B ALL). Ann. Hematol. 97 (5), 791-798.

Doan, T.N., Kirkpatrick, C.M., Walker, P., Slavin, M.A., Ananda-Rajah, M.R., Morrissey, C.O., et al., 2016. Primary antifungal prophylaxis in adult patients with acute lymphoblastic leukaemia: a multicentre audit. J. Antimicrob. Chemother. 71 (2), 497-505.

Drayson, M.T., Bowcock, S., Planche, T., Iqbal, G., Wood, J., Raynes, K., Pratt, G. Yong, K., Hawkey, P., Higgins, H., Dunn, J., 2017. Tackling Early Morbidity and Mortality in Myeloma (TEAMM): assessing the benefit of antibiotic prophylaxis and its effect on healthcare associated infections in 977 patients. Blood. 130 (Suppl 1), 903.

Drgona, L., et al., 2018. ESCMID Study Group for Infections in Compromised Hosts (ESGICH) Consensus Document on the safety of targeted and biological therapies: an infectious diseases perspective (Agents targeting lymphoid or myeloid cells surface antigens [II]: CD22, CD30, CD33. Clin. Microbiol. Infect. https://doi.org/10.1016/j. cmi.2018.03.022.

Dumontet, C., Hulin, C., Dimopoulos, M.A., Belch, A., Dispenzieri, A., Ludwig, H., et al., 2018. A predictive model for risk of early grade $\geq 3$ infection in patients with multiple myeloma not eligible for transplant: analysis of the FIRST trial. Leukemia 32, 1404-1413.

EASL, 2017. 2017 Clinical Practice Guidelines on the management of hepatitis B virus infection. J. Hepatol. 67 (2), 370-398.

Eichhorst, B., Fink, A.M., Bahlo, J., Busch, R., Kovacs, G., Maurer, C., Lange, E., et al., 2016. First-line chemoimmunotherapy with bendamustine and rituximab versus fludarabine, cyclophosphamide, and rituximab in patients with advanced chronic lymphocytic leukaemia (CLL10): an international, open-label, randomised, phase 3, non-inferiority trial. Lancet Oncol. 17 (July 7), 928-942.

Foà, R., Vitale, A., Vignetti, M., Meloni, G., Guarini, A., De Propris, M.S., et al., 2011 Dasatinib as first-line treatment for adult patients with Philadelphia chromosomepositive acute lymphoblastic leukemia. Blood 118 (25), 6521-6528.

Forconi, F., Moss, P., 2015. Perturbation of the normal immune system in patients with CLL. Blood. 126, 573-581.

Francis, S., Karanth, M., Pratt, G., Starczynski, J., Hooper, L., Fegan, C., et al., 2006. The effect of immunoglobulin $\mathrm{VH}$ gene mutation status and other prognostic factors on the incidence of major infections in patients with chronic lymphocytic leukemia. Cancer. 107 (September 5), 1023-1033. 
Freedberg, De, Bhadelia, N., Poneros, Jm, Oster, Mw., 2013. Visceral varicella in a patient with chronic lymphocytic leukemia treated with Fludarabine: a case report. Clin. Lymphoma Myeloma Leuk. 13, 90-92.

Furman, R.R., Sharman, J.P., Coutre, S.E., Cheson, B.D., Pagel, J.M., Hillmen, P., et al., 2014. Idelalisib and rituximab in relapsed chronic lymphocytic leukemia. N. Engl. J. Med. 370, 997-1007.

Gafter-Gvili, A., et al., 2016. Infections associated with bendamustine containing regimens in hematological patients: a retrospective multi-center study. Leuk. Lymphoma. https://doi.org/10.3109/10428194.2015.1046862.

Ghiridhar, K.V., Shanafelt, T., Tosh, P.K., 2017. Disseminated herpes Zoster in chronic lymphocytic leukemia (CLL) patients treated with B-cell receptor pathway inhibitors. Leuk. Lymphoma 58, 1973-1976.

Goede, V., Fischer, K., Busch, R., Engelke, A., Eichhorst, B., Wendtner, C.M., et al., 2014 Obinutuzumab plus chlorambucil in patients with CLL and coexisting conditions. N. Engl. J. Med. 370 (12), 1101-1110.

Gopal, A.K., et al., 2012. Safety and efficacy of brentuximab vedotin for Hodgkin lymphoma recurring after allogeneic stem cell transplantation. Blood. https://doi. org/10.1182/blood-2011-12-397893.

Green, H., Paul, M., Vidal, L., Leibovici, L., 2007. Prophylaxis for Pneumocystis pneumonia (PCP) in non-HIV immunocompromised patients. Cochrane Database Syst. Rev. (3) CD005590.

Guillermin, Y., Herbaux, C., Subtil, F., Aurran-Schleinitz, T., Cymbalista, F., Letestu, R., et al., 2018. Characteristics of chronic lymphocytic leukemia patients achieving 5+ years of remission after FC-based first-line treatment: retrospective observations from the FILO group. Am. J. Hematol. 93 (January 1), E24-E27.

Gulia, S., Dangi, U., Biswas, S., Kelkar, R., Menon, H., Sengar, M., 2014. Prevalence and patterns of cytomegalovirus DNAemia in adult patients with acute lymphoblastic leukemia on chemotherapy. Leuk. Lymphoma 55 (5), 1209-1211.

Hensel, M., Kornacker, M., Yammeni, S., Egerer, G., Ho, A.D., 2003. Disease activity and pretreatment, rather than hypogammaglobulinaemia, are major risk factors for infectious complications in patients with chronic lymphocytic leukaemia. Br. J. Haematol. 122, 600-606.

Hill, J.A., Li, D., Hay, K.A., Green, M.L., Cherian, S., Chen, X., et al., 2018. Infectious complications of CD19-targeted chimeric antigen receptor-modified T-cell immunotherapy. Blood 131 (1), 121-130.

Hillmen, P., Robak, T., Janssens, A., Babu, K.G., Kloczko, J., Grosicki, S., et al., 2015. Chlorambucil plus ofatumumab versus chlorambucil alone in previously untreated patients with chronic lymphocytic leukaemia (COMPLEMENT 1): a randomised, multicentre, open label phase 3 trial. Lancet. 385 (May 9980), 1873-1883.

Honeyman, F., Tavernier, E., Richez, V., Leguay, T., Tinquaut, F., Le Clech, L., et al., 2016. Epidemiology of bacterial infections during induction chemotherapy in adult patients with acute lymphoblastic leukemia (ALL): analysis of the Graall-2005 study. Blood 128 (2777).

Huang, B.H., Li, J., Liu, J.R., Gu, J.L., 2009. The clinical features and risk factors for invasive fungal infection in multiple myeloma. Zhonghua Nei Ke Za Zhi 48 (12), 1026-1030.

Huang, C.-T., Liu, C.-J., Ko, P.-S., Liu, C.-J., Yu Y-B, Hsiao L.-T., et al., 2017. Risk factors and characteristics of blood stream infections in patients with newly diagnosed multiple myeloma. BMC Infect. Dis. 17, 33.

Jabbour, E., Ravandi, F., Kebriaei, P., Huang, X., Short, N.J., Thomas, D., et al., 2018. Salvage chemoimmunotherapy with inotuzumab ozogamicin combined with MiniHyper-CVD for patients with relapsed or refractory Philadelphia chromosomenegative acute lymphoblastic leukemia: a phase 2 clinical trial. JAMA Oncol. 4 (2), 230-234.

Joffe, E., Ariela Arad, N., Bairey, O., et al., 2018. Persistently low lymphocyte counts after FCR therapy for chronic lymphocytic leukemia are associated with longer overall survival. Hematol. Oncol. 36, 128-135.

Johnsrud, A.J., Johnsrud, A.J., Susanibar, S.A., Kamimoto, J.J., Kothari, A., Burgess, M., et al., 2020. Infectious and immunological sequelae of daratumumab in multiple myeloma. Br. J. Haematol. Jul 5. doi: 10.1111/bjh.15433. [Epub ahead of print].

Jones, J.A., Robak, T., Brown, J.R., Awan, F.T., Badoux, X., Coutre, S., et al., 2017a. Efficacy and safety of idelalisib in combination with ofatumumab for previously treated chronic lymphocytic leukaemia: an openlabel, randomised phase 3 trial. Lancet Haematol. 4 e114-e26.

Jones, J.A., Robak, T., Brown, J.R., Awan, F.T., Badoux, X., Coutre, S., et al., 2017b. Efficacy and safety of idelalisib in combination with ofatumumab for previously treated chronic lymphocytic leukaemia: an open-label, randomised phase 3 trial. Lancet Haematol. 4 (March 3) e114-e126.

Jung, S.H., Kang, S.J., Jang, H.C., Ahn, J.S., Yang, D.H., Lee, S.S., Kim, Y.K., Kim, H.J., Lee, J.J., 2014. Effect of levofloxacin prophylaxis for prevention of severe infections in multiple myeloma patients receiving bortezomib-containing regimens. Int. J. Hematol. 100 (5), 473-477.

Kamber, C., Zimmerli, S., Suter-Riniker, F., Mueller, B.U., Taleghani, B.M., Betticher, D. Zander, T., Pabst, T., 2015. Varicella zoster virus reactivation after autologous SCT is a frequent event and associated with favorable outcome in myeloma patients. Bone Marrow Transplant. 50 (4), 573-578.

Kantarjian, H.M., DeAngelo, D.J., Stelljes, M., Martinelli, G., Liedtke, M., Stock, W., et al., 2016. Inotuzumab ozogamicin versus standard therapy for acute lymphoblastic leukemia. N. Engl. J. Med. 375 (8), 740-753.

Kantarjian, H., Stein, A., Gökbuget, N., Fielding, A.K., Schuh, A.C., Ribera, J.M., et al., 2017. Blinatumomab versus chemotherapy for advanced acute lymphoblastic leukemia. N. Engl. J. Med. 376 (9), 836-847.

Kantarjian, H., Ravandi, F., Short, N.J., Huang, X., Jain, N., Sasaki, K., et al., 2018. Inotuzumab ozogamicin in combination with low-intensity chemotherapy for older patients with Philadelphia chromosome-negative acute lymphoblastic leukaemia: a single-arm, phase 2 study. Lancet Oncol. 19 (2), 240-248.
Kim, S.J., Kim, K., Kim, B.S., Lee, H.J., Kim, H., Lee, N.R., et al., 2008a. Bortezomib and the increased incidence of herpes zoster in patients with multiple myeloma. Clin. Lymphoma Myeloma 8 (4), 237-240.

Kim, S.J., Kim, K., Kim, B.S., Lee, H.J., Kim, H., Lee, N.R., et al., 2008b. Bortezomib and the increased incidence of herpes zoster in patients with multiple myeloma. Clin. Lymphoma Myeloma 8 (4), 237-240.

Knauf, W.U., Lissichkov, T., Aldaoud, A., Liberati, A., Loscertales, J., Herbrecht, R., et al., 2009. Phase III randomized study of bendamustine compared with chlorambucil in previously untreated patients with chronic lymphocytic leukemia. J. Clin. Oncol. 27, 4378-4384.

Koehler, P., Hamprecht, A., Bader, O., Bekeredjian-Ding, I., Buchheidt, D., Doelken, G., et al., 2017. Epidemiology of invasive aspergillosis and azole resistance in patients with acute leukaemia: the SEPIA Study. Int. J. Antimicrob. Agents 49 (2), 218-223.

Kurosawa, M., Yonezumi, M., Hashino, S., Tanaka, J., Nishio, M., Kaneda, M., Ota, S., Koda, K., Suzuki, N., Yoshida, M., Hirayama, Y., Takimoto, R., Torimoto, Y., Mori, A., Takahashi, T., Iizuka, S., Ishida, T., Kobayashi, R., Oda, T., Sakai, H., Yamamoto, S., Takahashi, F., Fukuhara, T., 2012. Epidemiology and treatment outcome of invasive fungal infections in patients with hematological malignancies. Int. J. Hematol. 96 (6), 748-757.

Ljungman, P., de la Camara, R., Crocchiolo, R., et al., 2017. CMV update. In: 7th European Conference on Infections in Leukemia. Sept 23rd, 2017 (France).

Marchesi, F., Pimpinelli, F., Ensoli, F., Mengarelli, A., 2018. Cytomegalovirus infection in hematologic malignancy setting other than the allogeneic transplant. Hematol. Oncol. 36, 381-391.

Mariette, C., Tavernier, E., Hocquet, D., Huynh, A., Isnard, F., Legrand, F., et al., 2017. Epidemiology of invasive fungal infections during induction therapy in adults with acute lymphoblastic leukemia: a GRAALL-2005 study. Leuk. Lymphoma 58 (3), $586-593$.

Martell, M.P., Atenafu, E.G., Minden, M.D., Schuh, A.C., Yee, K.W., Schimmer, A.D., et al., 2013. Treatment of elderly patients with acute lymphoblastic leukaemia using a paediatric-based protocol. Br. J. Haematol. 163 (4), 458-464.

Maury, S., Chevret, S., Thomas, X., Heim, D., Leguay, T., Huguet, F., et al., 2016. Rituximab in B-Lineage adult acute lymphoblastic leukemia. N. Engl. J. Med. 375 (11), 1044-1053.

Mehta-Shah, N., Younes, A., 2015. Novel targeted therapies in diffuse large B-Cell lymphoma. Semin. Hematol. 52, 126-137.

Mellinghoff, S.C., Panse, J., Alakel, N., Behre, G., Buchheidt, D., Christopeit, M., et al., 2018. Primary prophylaxis of invasive fungal infections in patients with haematological malignancies: 2017 update of the recommendations of the Infectious Diseases Working Party (AGIHO) of the German Society for Haematology and Medical Oncology (DGHO). Ann. Hematol. 97 (2), 197-207.

Merchardt, T., Weiss, L., Greil, R., Egle, A., 2013. Viral infections and their management in patients with chronic lymphocytic leukemia. Leuk. Lymphoma 54, 1602-1613.

Michallet, A.S., Aktan, M., Hiddemann, W., Ilhan, O., Johansson, P., Laribi, K., et al., 2018. Rituximab plus bendamustine or chlorambucil for chronic lymphocytic leukemia: primary analysis of the randomized. open-label MABLE study Haematologica 103 (4), 698-706.

Moreira, J., Rabe, K.G., Cerhan, J.R., Kay, N.E., Wilson, J.W., Call, T.G., et al., 2013. Infectious complications among individuals with clinical monoclonal B-cell lymphocytosis (MBL): a cohort study of newly diagnosed cases compared to controls. Leukemia. 27 (January 1), 136-141.

Morrison, V.A., Rai, K.R., Peterson, B.L., Kolitz, J.E., Elias, L., Appelbaum, F.R., et al., 2001. Impact of therapy with chlorambucil, fludarabine, or fludarabine plus chlorambucil on infections in patients with chronic lymphocytic leukemia: intergroup Study Cancer and Leukemia Group B 9011. J. Clin. Oncol. 19, 3611-3621.

Munõz, R.G., Izquierdo-Gil, A., Munõz, A., Roldan-Galiacho, V., Rabasa, P., Panizo, C., 2014. Lymphocyte recovery is impaired in patients with chronic lymphocytic leukemia and indolent non-Hodgkin lymphoma treated with Bendamustine plus Rituximab. Ann. Hematol. 93, 1879-1887.

Musto, P., Brugiatelli, M., Carotenuto, M., 1995. Prophylaxis against infections with intravenous immunoglobulins in multiple myeloma. Br. J. Haematol. 89 (4), 945-946.

Nachbaur, D., Angelova, O., Orth-Höller, D., Ditlbacher, A., Lackner, M., Auberger, J., et al., 2015. Primary antifungal prophylaxis with micafungin in patients with haematological malignancies: real-life data from a 4retrospective single-centre observational study. Eur. J. Haematol. 94 (3), 258-264.

Nguyen, Q., Estey, E., Raad, I., Rolston, K., Kantarjian, H., Jacobson, K., et al., 2001. Cytomegalovirus pneumonia in adults with leukemia: an emerging problem. Clin. Infect. Dis. 32 (February 4), 539-545.

Nicolato, A., Nouér, S.A., Garnica, M., Portugal, R., Maiolino, A., Nucci, M., 2016. Invasive fungal diseases in patients with acute lymphoid leukemia. Leuk. Lymphoma 57 (9), 2084-2089.

Nørgaard, M., Larsson, H., Pedersen, G., Schønheyder, H.C., Sørensen, H.T., 2006. Risk of bacteraemia and mortality in patients with haematological malignancies. Clin. Microbiol. Infect. 12 (3), 217-223.

Nosari, A., 2012. Infectious complications in chronic lymphocytic leukemia. Mediterr. J. Hematol. Infect. Dis. 4 (1).

Nosari, A., Pioltelli, M.L., Riva, M., Marbello, L., Nichelatti, M., Greco, A., et al., 2014. Invasive fungal infections in lymphoproliferative disorders: a monocentric retrospective experience. Leuk. Lymphoma 55 (August 8), 1844-1848.

O'Connor, O.A., Lue, J.K., Sawas, A., Amengual, J.E., Deng, C., Kalac, M., Falchi, L., Marchi, E., Turenne, I., Lichtenstein, R., Rojas, C., Francescone, M., Schwartz, L., Cheng, B., Savage, K.J., Villa, D., Crump, M., Prica, A., Kukreti, V., Cremers, S., Connors, J.M., Kuruvilla, J., 2018. Brentuximab vedotin plus bendamustine in 
relapsed or refractory Hodgkin's lymphoma: an international, multicentre, singlearm, phase 1-2 trial. Lancet Oncol. 19 (February 2), 257-266.

Oken, M.M., Pomeroy, C., Weisdorf, D., Bennett, J.M., 1996. Prophylactic antibiotics for the prevention of early infection in multiple myeloma. Am. J. Med. 100 (6), 624-628.

Pagano, L., Caira, M., Candoni, A., Offidani, M., Fianchi, L., Martino, B., et al., 2006a. The epidemiology of fungal infections in patients with hematologic malignancies: the SEIFEM-2004 study. Haematologica. 91 (August 8), 1068-1075.

Pagano, L., et al., 2006b. The epidemiology of fungal infections in patients with hematologic malignancies: the SEIFEM-2004 study. Haematologica 91 (8), 1068-1075.

Pagano, L., Busca, A., Candoni, A., Cattaneo, C., Cesaro, S., Fanci, R., et al., 2017a. SEIFEM (Sorveglianza Epidemiologica Infezioni Fungine nelle Emopatie Maligne) Group; Other Authors: Risk stratification for invasive fungal infections in patients with hematological malignancies: SEIFEM recommendations. Blood Rev. 31 (2), 17-29.

Pagano, L., Busca, A., Candoni, A., Cattaneo, C., Cesaro, S., Fanci, R., et al., 2017b. Risk stratification for invasive fungal infections in patients with hematological malignancies: SEIFEM recommendations. Blood Rev. 31 (March 2), 17-29.

Palumbo, A., Bringhen, S., Rossi, D., Cavalli, M., Larocca, A., Ria, R., et al., 2010. Bortezomib-melphalan-prednisone-thalidomide followed by maintenance with bortezomib-thalidomide compared with bortezomib-melphalan-prednisone for initial treatment of multiple myeloma: a randomized controlled trial. J. Clin. Oncol. 28 (34), 5101-5109.

Palumbo, A., Cavallo, F., Gay, F., Di Raimondo, F., Yehuda, D.B., Petrucci, M.T., et al., 2014. Autologous transplantation and maintenance therapy in multiple myeloma. N. Engl. J. Med. 371 (10), 895-905.

Park, S., Jung, C.W., Jang, J.H., Kim, S.J., Kim, W.S., Kim, K., 2015. Incidence of infection according to intravenous immunoglobulin use in autologous hematopoietic stem cell transplant recipients with multiple myeloma. Transpl. Infect. Dis. 17 (5), 679-687.

Park, J.H., Romero, F.A., Taur, Y., Sadelain, M., Brentjens, R.J., Hohl, T.M., et al., 2018. Cytokine release syndrome grade as a predictive marker for infections in patients with relapsed or refractory B-Cell acute lymphoblastic leukemia treated with chimeric antigen receptor t cells. Clin. Infect. Dis. 67 (4), 533-540.

Park, H., Youk, J., Shin, D.Y., Hong, J., Kim, I., Kim, N.J., Lee, J.O., Bang, S.M., Yoon, S. S., Park, W.B., Koh, Y., 2019. Micafungin prophylaxis for acute leukemia patients undergoing induction chemotherapy. BMC Cancer 19 (April 1), 358.

Podhorecka, M., Markowicz, J., Szymczyk, A., Pawlowski, J., 2014. Target therapy in hematological malignances: new monoclonal antibodies. Int. Sch. Res. Not. https:// doi.org/10.1155/2014/701493.

Raanani, P., Gafter-Gvili, A., Paul, M., Ben-Bassat, I., Leibovici, L., Shpilberg, O., 2009. Immunoglobulin prophylaxis in chronic lymphocytic leukemia and multiple myeloma: systematic review and meta-analysis. Leuk. Lymphoma 50 (5), 764-772.

Raisch, D.W., Rafi, J.A., Chen, C., Bennett, C.L., 2016. Detection of cases of progressive multifocal leukoencephalopathy associated with new biologicals and targeted cancer therapies from the FDA's adverse event reporting system. Expert Opin. Drug Saf. https://doi.org/10.1080/14740338.2016.1198775.

Ravandi, F., O'Brien, S., 2006. Immune defects in patients with chronic lymphocytic leukemia. Cancer Immunol. Immunother. 55 (February 2), 197-209.

Reddy, K.R., Beavers, K.L., Hammond, S.P., Lim, J.K., Falck-Ytter, Y.T., 2015. American Gastroenterological Association Institute guideline on the prevention and treatment of hepatitis B virus reactivation during immunosuppressive drug therapy. Gastroenterology 148 (January 1), 215-219.

Redelman-Sidi, G., Michielin, O., Cervera, C., Ribi, C., Aguado, J.M., Fernández-Ruiz, M., Manuel, O., 2018. ESCMID Study Group for Infections in Compromised Hosts (ESGICH) Consensus Document on the safety of targeted and biological therapies: an infectious diseases perspective (Immune checkpoint inhibitors, cell adhesion inhibitors, sphingosine-1-phosphate receptor modulators and proteasome inhibitors). Clin. Microbiol. Infect. Jun;24 Suppl 2:S95-S107. doi: 10.1016/j. cmi.2018.01.030. Epub 2018 Feb 7.

Reinwald, M., Silva, J.T., Mueller, N.J., Fortún, J., Garzoni, C., de Fijter, J.W. Fernández-Ruiz, M., et al., 2018. ESCMID study group for infections in compromised hosts (ESGIGH) consensus document on the safety of targeted and biological therapies: and infectious disease perspective (intracellular signaling pathways: tyrosine kinase and mTOR inhibitors). Clin. Microbiol. Infect. 24 (Suppl 2), S53-S70.

Ribera, J.M., Oriol, A., Sanz, M.A., Tormo, M., Fernández-Abellán, P., del Potro, E., et al., 2008. Comparison of the results of the treatment of adolescents and young adults with standard-risk acute lymphoblastic leukemia with the Programa Español de Tratamiento en Hematología pediatric-based protocol ALL-96. J. Clin. Oncol. 26 (11), 1843-1849.

Ribera, J.M., García, O., Oriol, A., Gil, C., Montesinos, P., Bernal, T., et al., 2016. Feasibility and results of subtype-oriented protocols in older adults and fit elderly patients with acute lymphoblastic leukemia: results of three prospective parallel trials from the PETHEMA group. Leuk. Res. 41, 12-20.

Rijneveld, A.W., van der Holt, B., Daenen, S.M., Biemond, B.J., de Weerdt, O., Muus, P., et al., 2011. Intensified chemotherapy inspired by a pediatric regimen combined with allogeneic transplantation in adult patients with acute lymphoblastic leukemia up to the age of 40. Leukemia 25 (11), 1697-1703.

Rousselot, P., Coudé, M.M., Gokbuget, N., Gambacorti Passerini, C., Hayette, S., Cayuela, J.M., et al., 2016. Dasatinib and low-intensity chemotherapy in elderly patients with Philadelphia chromosome-positive ALL. Blood 128 (6), 774-782.

Safdar, A., Rodriguez, G.H., Mihu, C.N., Mora-Ramos, L., Mulanovich, V., Chemaly, R.F., et al., 2010. Infections in non-myeloablative hematopoietic stem cell transplantation patients with lymphoid malignancies: spectrum of infections, predictors of outcome and proposed guidelines for fungal infection prevention. Bone Marrow Transplant. 45 (February 2), 339-347.

Salles, G., et al., 2017. Efficacy and safety of idelalisib in patients with relapsed, rituximab- and alkylating agent-refractory follicular lymphoma: a subgroup analysis of a phase 2 study. Haematologica. https://doi.org/10.3324/ haematol.2016.151738.

San Miguel, J.F., Schlag, R., Khuageva, N.K., et al., 2008. Bortezomib plus melphalan and prednisone for initial treatment of multiple myeloma. New England J. Med. Surg. Collat. Branches Sci. 359, 906-917.

Santos, R., Ursu, O., Gaulton, A., Bento, A.P., Donadi, R.S., Bologa, C.G., et al., 2017. A comprehensive map of molecular drug targets. Nat. Rev. Drug Discov. 16, 19-34.

Saral, R., Ambinder, R.F., Burns, W.H., Angelopulos, C.M., Griffin, D.E., Burke, P.J., et al., 1983. Acyclovir prophylaxis against herpes simplex virus infection in patients with leukemia. A randomized, double-blind, placebo-controlled study. Ann. Intern. Med. 99 (6), 773-776.

Sehn, L.H., Hallek, M., Jurczak, W., Brown, J.R., Barr, P.M., Catalano, J., et al., 2016. A retrospective analysis of Pneumocystis Jirovecii Pneumonia infection in patients receiving Idelalisib in clinical trials. Blood 128 (3705).

Sive, J.I., Buck, G., Fielding, A., Lazarus, H.M., Litzow, M.R., Luger, S., et al., 2012. Outcomes in older adults with acute lymphoblastic leukaemia (ALL): results from the international MRC UKALL XII/ECOG2993 trial. Br. J. Haematol. 157 (4), 463-471.

Sørrig, R., Klausen, T.W., Salomo, M., Gimsing, Vangsted A., 2018. Risk factors for blood stream infections in multiple myeloma: a population-based study of 1154 patients in Denmark. Eur. J. Haematol. 101 (1), 21-27.

Stanzani, M., Lewis, R.E., Fiacchini, M., Ricci, P., Tumietto, F., Viale, P., et al., 2013. A risk prediction score for invasive mold disease in patients with hematological malignancies. PLoS One 26 (September 9), e75531.

Strati, P., Wierda, W., Burger, J., Ferrajoli, A., Tam, C., Lerner, S., et al., 2013. Myelosuppression after frontline fludarabine, cyclophosphamide, and rituximab in patients with chronic lymphocytic leukemia: analysis of persistent and new-onset cytopenia. Cancer. 119 (November 21), 3805-3811.

Styczynski, J., Reusser, P., Einsele, H., de la Camara, R., Cordonnier, C., Ward, K.N., et al., 2009. Management of HSV, VZV and EBV infections in patients with hematological malignancies and after SCT: guidelines from the Second European Conference on Infections in Leukemia. Bone Marrow Transplant. 43 (10), 757-770.

Sulis, M.L., Blonquist, T.M., Stevenson, K.E., Hunt, S.K., Kay-Green, S., Athale, U.H., et al., 2018. Effectiveness of antibacterial prophylaxis during induction chemotherapy in children with acute lymphoblastic leukemia. Pediatr. Blood Cancer 65 (5), e26952.

Sun, Y., Huang, H., Chen, J., Li, J., Ma, J., Li, J., et al., 2015. Invasive fungal infection in patients receiving chemotherapy for hematological malignancy: a multicenter, prospective, observational study in China. Tumour Biol. 36 (February 2), 757-767.

Sutton, E., Lopez, J.J., Dao, L., Wetter, D.A., 2016. Disseminated Herpes Zoster in chronic lymphocytic leukemia. J. Emerg. Med. 50, e159-160.

Swan, C.D., Reid, A.B., 2014. Three cases of presumed pneumocystis pneumonia in patients receiving bortezomib therapy for multiple myeloma. IDCases 1, 32-35.

Takaoka, K., Nannya, Y., Shinohara, A., et al., 2014. A novel scoring system to predict the incidence of invasive fungal disease in salvage chemotherapies for malignant lymphoma. Ann. Hematol. 93 (October 10), 1637-1644.

Tam Constantine, C.S., O'Brien, S., Wierda, W.G., Kantarjian, H., Wen, S., Do, K.A., et al., 2008. Long-term results of the fludarabine, cyclophosphamide, and rituximab regimen as initial therapy of chronic lymphocytic leukemia. Blood. 112 (August 4), 975-980.

Teh, B.W., Harrison, S.J., Worth, L.J., Spelman, T., Thursky, K.A., Slavin, M.A., 2015. Risks, severity and timing of infections in patients with multiple myeloma: a longitudinal cohort study in the era of immunomodulatory drug therapy. Br. J. Haematol. 171, 100-108.

Teh, B.W., Harrison, S.J., Worth, L.J., Thursky, K.A., Slavin, M.A., 2016. Infection risk with immunomodulatory and proteasome inhibitorebased therapies across treatment phases for multiple myeloma: a systematic review and meta-analysis. Eur. J. Cancer 67, 21-37.

Teng, J.C., Slavin, M.A., Teh, B.W., Lingaratnam, S.M., Ananda-Rajah, M.R., Worth, L.J., et al., 2015. Epidemiology of invasive fungal disease in lymphoproliferative disorders. Haematologica. 100 (November 11) e462-6.

The, B.W., Worth, L.J., Harrison, S.J., Thursky, K.A., Slavina, M.A., 2015. Risks and burden of viral respiratory tract infections in patients with multiple myeloma in the era of immunomodulatory drugs and bortezomib: experience at an Australian Cancer hospital. Support. Care Cancer 23 (7), 1901-1906.

Thomas, D.A., O'Brien, S., Faderl, S., Garcia-Manero, G., Ferrajoli, A., Wierda, W., et al., 2010. Chemoimmunotherapy with a modified hyper-CVAD and rituximab regimen improves outcome in de novo Philadelphia chromosome-negative precursor Blineage acute lymphoblastic leukemia. J. Clin. Oncol. 28 (24), 3880-3889.

Tillman, B.F., Pauff, J.M., Satyanarayana, G., Talbott, M., Warner, J.L., 2018. Systematic review of infectious events with the Bruton tyrosine kinase inhibitor ibrutinib in the treatment of hematologic malignancies. Eur. J. Haematol. 100, 325-334.

Tisi, M.C., Hohaus, S., Cuccaro, A., Innocenti, I., De Carolis, E., Za, T., et al., 2017. Invasive fungal infections in chronic lymphoproliferative disorders: a monocentric retrospective study. Haematologica. 102 (March 3) e108-e111.

Varughese, T., Taur, Y., Cohen, N., Palomba, M.L., Seo, S.K., Hohl, T.M., et al., 2018. Serious infections in patients receiving ibrutinib for treatment of lymphoid malignancies. Clin. Infect. Dis. 67 (August 5), 687-692.

Vesole, D.H., Oken, M.M., Heckler, C., Greipp, P.R., Katz, M.S., Jacobus, S., Morrow, G. R., University of Rochester Cancer Center and the Eastern Cooperative Oncology Group, 2012. Oral antibiotic prophylaxis of early infection in multiple myeloma: a URCC/ECOG randomized phase III study. Leukemia 26 (12), 2517-2520. 
Vignetti, M., Fazi, P., Cimino, G., Martinelli, G., Di Raimondo, F., Ferrara, F., et al., 2007. Imatinib plus steroids induces complete remissions and prolonged survival in elderly Philadelphia chromosome-positive patients with acute lymphoblastic leukemia without additional chemotherapy: results of the Gruppo Italiano Malattie Ematologiche dell'Adulto (GIMEMA) LAL0201-B protocol. Blood 109 (9), 3676-3678.

Visentin, A., Gurrieri, C., Imbergamo, S., Lessi, F., Di Maggio, S.A., Frezzato, F., et al., 2017. Epidemiology and risk factors of invasive fungal infections in a large cohort of patients with chronic lymphocytic leukemia. Hematol. Oncol. 35 (December 4), 925-928.

Wadhwa, P.D., Morrison, V.A., 2006. Infectious complications of chronic lymphocytic leukemia. Semin Oncol. 33 (April 2), 240-249.

Wang, Y., Xing, Y., Chen, L., Meng, T., Li, Y., Xie, J., et al., 2018. Fluconazole versus mould-active triazoles for primary antifungal prophylaxis in adult patients with acute lymphoblastic leukemia: clinical outcome and cost-effectiveness analysis. Int J. Hematol. 107 (2), 235-243.

Widjajanto, P.H., Sumadiono, S., Cloos, J., Purwanto, I., Sutaryo, S., Veerman, A.J., 2013. Randomized double blind trial of ciprofloxacin prophylaxis during induction treatment in childhood acute lymphoblastic leukemia in the WK-ALL protocol in Indonesia. J. Blood Med. 4, 1-9.

Williams, A., Baran, A., Meacham, P., Feldman, M., Valencia, H., Newsom-Stewart, C., et al., 2018. Analysis of the risk of infection in patients with chronic lymphocytic Leukemia in the era of novel therapies. Leuk. Lymphoma 59 (3), 625-632.

Wolf, J., Tang, L., Flynn, P.M., Pui, C.H., Gaur, A.H., Sun, Y., et al., 2017. Levofloxacin prophylaxis during induction therapy for pediatric acute lymphoblastic leukemia. Clin. Infect. Dis. 65 (11), 1790-1798.

Wongso, D., Fuchs, M., Plütschow, A., et al., 2013. Treatment-related mortality in patients with advanced-stage hodgkin lymphoma: an analysis of the german hodgkin study group. J. Clin. Oncol. 31 (August 22), 2819-2824.

Yousef, A.A., Fryer, C.J., Chedid, F.D., Abbas, A.A., Felimban, S.K., Khattab, T.M., 2004 A pilot study of prophylactic ciprofloxacin during delayed intensification in children with acute lymphoblastic leukemia. Pediatr. Blood Cancer 43 (6), 637-643.

Zelenetz, A.D., Barrientos, J.C., Brown, J.R., Coiffier, B., Delgado, J., Egyed, M., et al., 2017. Idelalisib or placebo in combination with bendamustine and rituximab in patients with relapsed or refractory chronic lymphocytic leukaemia: interim results from a phase 3, randomised, double-blind, placebo-controlled trial. Lancet Oncol. 18 (March 3), 297-311.

Alessandro Busca graduated in Medicine from the University of Turin in 1986, and completed the Specialization in Pediatrics in 1990 and in Hematology in 1998. During 1991 and 1992, he received postdoctoral training at the Fred Hutchinson Cancer Research Center of Seattle. Since november 2017 he is the chairmen of the SEIFEM Group. Dr Busca has published more than 130 articles in peer-reviewed Journals.

Cattaneo was granted MD degree in 1994 at University of Milan, Italy. She was postgraduated in Hematology in 1998 (University of Milan, Italy) and in Infectious Diseases in 2006 (University of Brescia, Italy). She is Head of Hematology inpatient unit ASST-Spedali Civili in Brescia, Italy.

Elena Decarolis. PhD, she graduated in biological sciences at the University "La Sapienza", has a specialty degree in microbiology and a $\mathrm{PhD}$ degree in general and clinical microbiology at the UCSC. Member of the Executive Committee of the Italian Federation of Human and Animal Mycology (FIMUA) and Head of the Micology Laboratory at Fondazione Policlinico Gemelli, IRCCS, Rome. Her research area involve the development and evaluation of molecular tests and MALDI-TOF mass spectrometry based tests for the diagnosis and characterization of microbial infections and the molecular mechanisms leading to the antimicrobial resistance of pathogenic microrganisms.

Gianpaolo Nadali obtained his Medical Degree at the University of Verona (Italy) in 1988 and in 1991 he graduated in Clinical Hematology at the Postgraduate School of Hematology of the University of Verona. Thereafter he was Assistant Professor of Hematology at the Department of Clinical and Experimental Medicine of the University of Verona, Italy.

Massimo Offidani was granted MD degree in May 1988 at Ancona University Postgraduate and School Certificate in Hematology degree in November 1995. Thereafter he started working as a Clinical Hematologist at the Department of Hematology of Ancona where he works until now. He is chief of clinical and research in Multiple Myeloma and Infection in Immunocompromise host in his Institute. He is author and co-author of more than 100 peer-review publications in their fields of interest. He is also member of the principal national and international Hematology associations.

Marco Picardi Naples Italy received his MD degree in 1991 and completed the Specialization in Hematology at the Federico II University in 1995 and in Internal Medicine in 2001. He currently works as Associate Professor in the Hematology Department of Federico II University and has a more than ten-year expertise in ultrasound diagnostic procedure field and treatment for lymphomas and in systemic infections for immunocompromised patients.

Anna Candoni, was graduated in Medicine from the University of Trieste in 1992 and post-graduate in Hematology (1996) and Clinical Oncology (2006). Since Jan $2008 \mathrm{Dr}$ Candoni is the chief of the Acute Leukemia Section, Division of Hematology and SCT, University of Udine-Italy. Her interests include acute myeloid and lymphoid leukemias, myelodysplastic syndromes, infections in hematologic patients and bone marrow transplantation. Dr Candoni has published more than 180 articles and has authored more than 450 abstracts.

Elena Ceresoli completed her medical degree in 2008 and hematological degree in 2017 at Tor Vergata University in Rome. She currently works as clinical hematologist at the Department of Hematology, San Giovanni Addolorata in Rome.

Marianna Criscuolo graduated in Medicine and Surgery at Catholic University of Sacred Heart, Rome in 2007. She completed her Fellowship in Hematology in 2014 and PhD degree in Oncologic Sciences in 2017 at Catholic University of Sacred Heart, Rome. She is currently a physician at Hematology Department at Fondazione Policlinico Universitario A. Gemelli IRCCS, Rome and involved in the clinical care of onco-hematologic patients.

Mario Delia attended Medical School at University of Bari and was granted MD degree in 1999. Thereafter, he started working as a resident in the Hematology Section of University of Bari obtaining the specialization in Hematology in 2004. He awarded his PhD degree in Doctor of Clinical Immunology (University of Bari - 2007 Visiting Scientist HSR Milan Italy) in 2008. He currently works as a phisician at the Section of Hematology, Policlinico di Bari - University of Bari. The study field of interest is acute leukemias, stem cell transplantation, infections in hematology.

Roberta Della Pepa was granted an MD degree in 2008 and completed the Specialization in Hematology in 2015 at the Federico II University of Naples. Thereafter, she awarded her $\mathrm{PhD}$ degree in "Advanced biomedical-surgical therapies" in 2019. She currently works as a resident doctor in the Hematology Department of Federico II University in lymphomas and systemic infections for immunocompromised patients fields.

Ilaria Del Principe completed her MD degree (1997) and PhD degree (2005) at Tor Vergata University of Rome, Italy. She is currently a researcher, Chair of Hematology of the Tor Vergata University of Rome. Her research focus is the acute myeloid leukemia, acute and chronic lymphocytic leukemia and infections in onco-hematologic patients.

Rosa Fanci. Degree in Medicine and Surgery in 1979 at the University of Florence and post-degree in Clinical and Laboratory Haematology (1983) and in Infectious Diseases (1989). Senior researcher in the Department of Haematology, University of Florence and Assistant Professor in Haematology at the same university. National academic qualification as Associate Professor in Infectious Diseases

Francesca Farina graduated from Milano-Bicocca University in 2009 and completed her Fellowship in Hematology at Pavia University in 2014. She is currently involved in the clinical care of hematological patients in the Hematology and Bone Marrow Transplant Unit at IRCCS San Raffaele, Milano

Nicola Fracchiolla. Degree in Medicine and Surgery in 1992 at the Milan University. Specialist in Hematology and Oncology. Researcher at the College of Physician and Surgeons, Columbia University, NY, NY (1995-1996). Active member of Gimema, Seifem, Campus ALL and REL (Rete Ematologica Lombarda) study groups. Responsible of "Acute Leukemias", "Infections in OncoHematologic patients", Pharmacovigilance" programs and of Hematologic ward at Fondazione IRCCS Ca' Granda-Ospedale Maggiore Policlinico, Milan, Italy.

Claudia Giordano attended Medical School at the Federico II University of Naples and was granted an MD degree in 2015 with a thesis on monoclonal antibodies for Hodgkin lymphoma. She is currently attending the last year of Specialization in the Department of Hematology of the Policlinico Federico II and will be starting soon a $\mathrm{PhD}$ program. Her field of study are treatment approaches for B-cell lymphomas and infections in immunocompromised patients.

Michele Malagola graduated in Bologna University in 2000 and completed his Fellowship in Hematology at the Seragnoli Institute of Hematology of Bologna University in 2004. He is currently Associate Professor of Hematology at Brescia University and involved in the clinical care of hematological patients in the Bone Marrow Transplant Unit of ASST Spedali Civili in Brescia.

Marchesi obtained his degree in Medicine at University Campus Bio-Medico of Rome in 2007. He completed his specialization in Hematology in 2011. He has been working as clinical hematologist since 2011. Currently, he works in the Hematology and Stem Cell Transplant Unit of Regina Elena National Cancer Institute, managing hematologic malignancies, particularly acute leukemias and lymphomas.

Monica Piedimonte is a Physician-Scientist, $\mathrm{PhD}$ student, and member of the clinical faculty in the Department of Clinical and Molecular Medicine of Sapienza University of Rome. As a resident she was interested in the critical hematological patient with particular attention to infectious complications. During her $\mathrm{PhD}$, she extended scientific interest to translational research, giving her contribution to the understanding of the metabolism of B-cell malignancies and drug resistance

Lucia Prezioso completed the six-year clinical medicine program at the University of Parma in 2005 and got specialization in Internal Medicine in the 2009. She awarded her $\mathrm{PhD}$ degree in Systemic Physiopathology in 2014. Since 2011 she works as a Physician at 
the Bone Marrow and Hematology Unit, focusing on transplant activity, mainly on $\mathrm{T}$ depleted allogenic transplantation, and infection control program. Angelica Spolzino attended medical school at Parma University and was granted MD degree in 2012. She obtained a Postgraduate Master in Stem Cell and Regenerative Medicine in 2013 and specialized in Hematology in 2018. Thereafter, she started studying for her PhD degree at Parma University. Her main research areas are microbiome study and major infections in immunocompromised patients.

Angela Maria Quinto. Education: 2014 Specialization in Hematology and Clinical Immunology, Università degli Studi di Padova; 2008 Medical Degree, Università degli Studi Di Bari. Professional Experience: from 2016 Medical Doctor, IRCCS ISTITUTO TUMORI "GIOVANNI PAOLO II", BARI, ITALY; from 2015 to 2016 Medical Doctor, Hospital "Madonna delle Grazie", MATERA, ITALY.

Maria Chiara Tisi completed her MD degree (2008), fellowship in Hematology (2014) and $\mathrm{PhD}$ degree in Oncologic Science (2017) at Università Cattolica del Sacro Cuore in Rome, discussing thesis on lymphomas and their prognosis. In 2016 she started working as consultant at the Hematology and Bone Marrow Transplant Department at Ospedale S. Bortolo in Vicenza, continuing clinical studies on lymphoma and infections, and as leader of CAR-T team in Vicenza.

Fabio Trastulli attended Medical School at the University of Rome "La Sapienza" and was granted an MD degree in 2014 with a thesis on "Diagnostic work-up of Autoimmune Hemolytic Anemia" and completed the Specialization in Hematology at the Federico II University in 2019. He is currently attending a PhD program at Department of Hematology of the Policlinico Federico II. His field of study are treatment approaches for B-cell lymphomas and infections in immunocompromised patients.
Enrico Maria Trecarichi graduated in Medicine and Surgery in Catholic University, Rome in 2002; completed his Fellowship in Infectious Diseases in 2006 and PhD degree in Infectious and Tropical diseases in 2012 at the Catholic University, Rome. He is currently Associate Professor of Infectious Diseases at "Magna Graecia" University of Catanzaro and involved in the clinical care at Infectious and Tropical Diseases at Teaching Hospital "Mater Domini" of Catanzaro. His research area mainly includes studies on bacterial and fungal infections in general population and in immunocompromised (in particular, oncohematological) patients, particularly focusing on epidemiological and clinical impact of antimicrobial resistance.

Patrizia Zappasodi, was graduated in Medicine from the University of Genova in 1994 and post-graduate in Hematology in 2000 at the University of Pavia.

Mario Tumbarello. Associate Professor of Infectious Diseases at Catholic University of Sacred Heart in Rome. Author of more than 200 papers cited in PubMed, the majority of them on epidemiology and clinical aspects of healthcare-associated infections caused by antimicrobial-resistant bacteria and fungi. Invited speaker at many international conferences. He directs research groups on multidrug-resistant infections and participates to board for management of clinical trials.

Livio Pagano is Associated Professor of Hematology and Head of "Geriatric Hematology and Rare Hematological malignancies" Unit. He is the last Chairman of EORTC- Infectious Disease Group. Actually President of SEIFEM. Fellow of European Confederation of Medical Mycology (FECMM). Past president of FIMUA (Federazione Italiana Micologia Umana ed Animale. 